$$
\begin{aligned}
& \text { تأثير هيدرويرايمينَ و ييرى بذر بر ويزگى هاى جوانهزنى و بيوشيميايى بذر لوبيا جيتى } \\
& \text { تحت تيمار شورى (Phaseolus vulgaris) } \\
& \text { مجيد قنبرى اء"، سيد على محمد مدرس ثانوى '، على مختصى بيدَّلى "، يرنيان طالبى سيهسران " }
\end{aligned}
$$

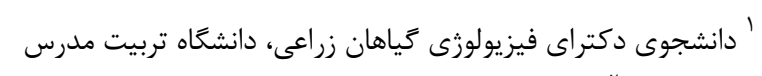

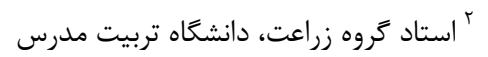

$$
\begin{aligned}
& \text { r }
\end{aligned}
$$

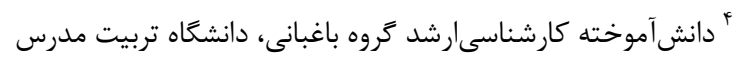

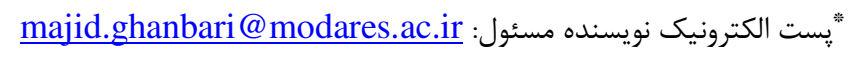

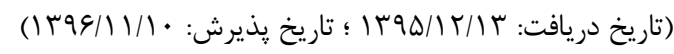

اين يزوهش با هدف بررسى اثر هيدرويرايمينت و يِيرى بذر بر ويزكى هاى جوانهزنى و آنزيمى بذر لوبيا

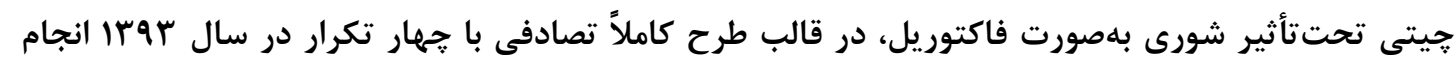

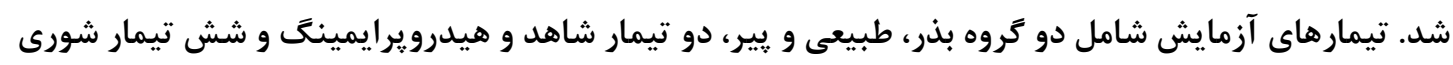

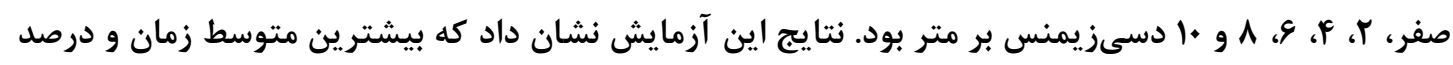

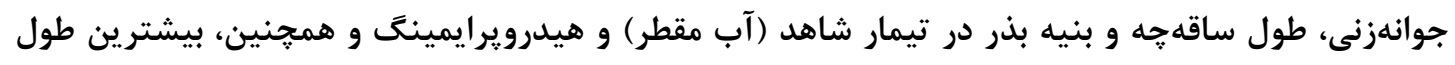

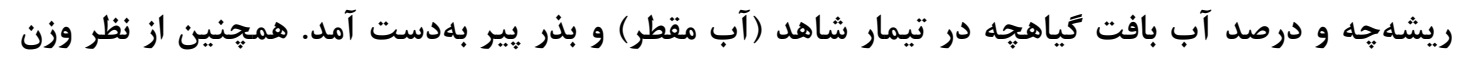

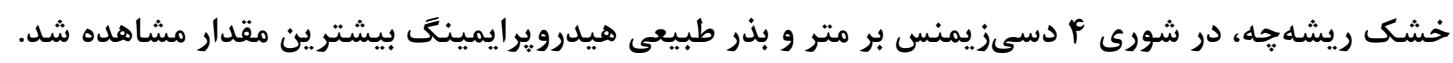

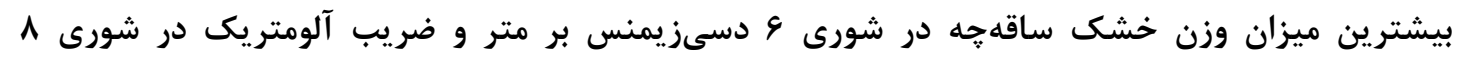

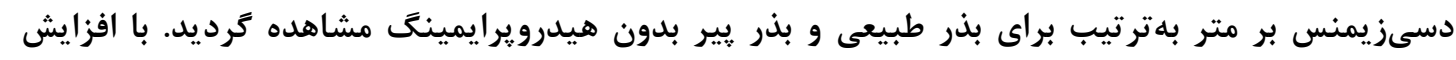

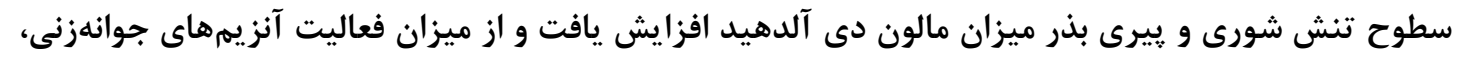

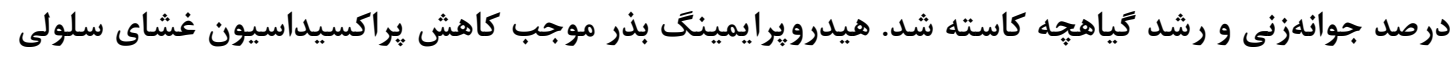

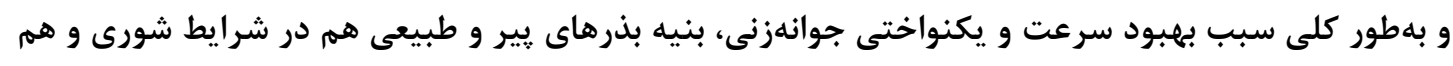

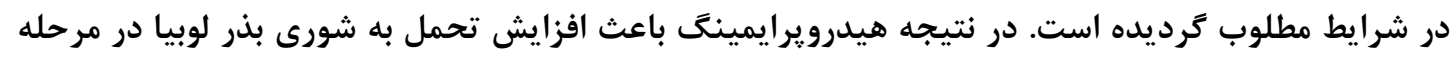

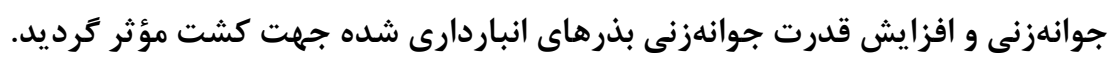
وازههاى كليدى: يِيرى بذر، جوانهزنى، شاخصهاى رشدى كياهجه، نمك، هيدراسيون بيش كاشت

$$
\begin{aligned}
& \text { جنبdهاى نو آورى }
\end{aligned}
$$

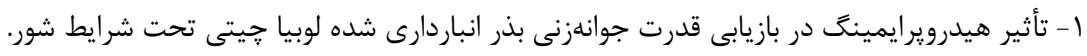

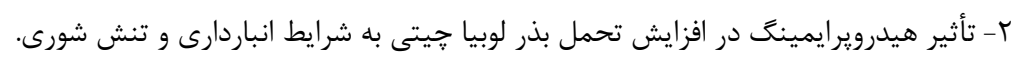

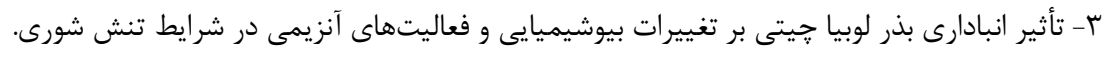

DOI: $10.29252 /$ yujs.4.2.37 
حساس زندگى گياهى است. استقرار كياهجه حاصل جوانهزنى سريع و يكنواخت و توانايى جوانهزنى در لئى شرايط تنشهاى غير زيستى است (ويندور لو و همكاران،

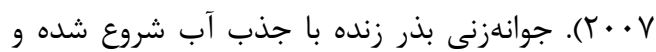
بلهوسيله حوادث متوالى بيوشيميايى در بذر شامل فعال

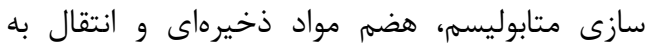

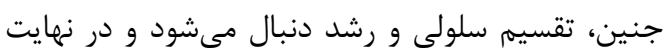
با خروج محورهاى جنينى يايان مى يابد. جوانهزنى شامل

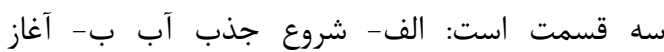

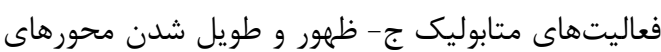

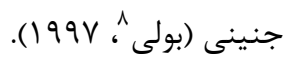

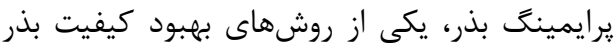

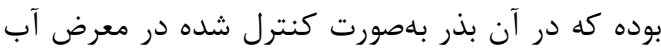

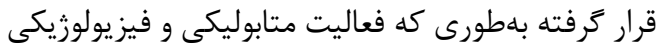
مختلف در سطوح متفاوت رطوبتى درون بذر براى جوانه زنى پيش از اينكه ريشهجه از بذر خارج شود، اتفاق

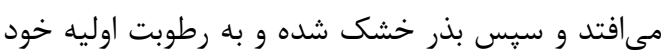

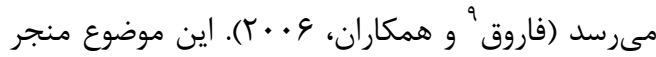

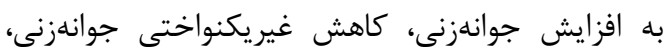

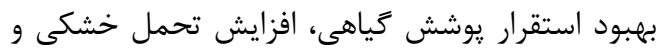

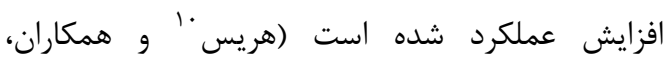
( $($. . .

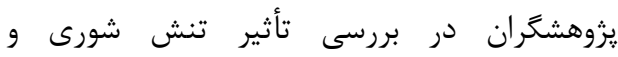

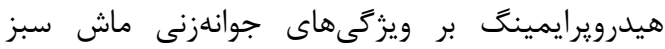
دريافتند كه بلهطور كلى، هيدرويرايمينگ توانسته است از طريق ارتقاء سرعت و يكنواختى جوانهزنى و افزايش

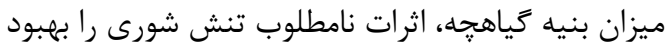

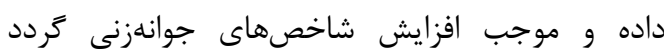

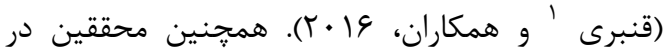
بررسى تاثير هيدرو و هالويرايمينَ بر جوانه زنى بذر و و

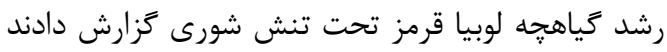

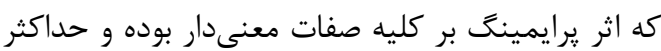
بهبود جوانهزنى در بذرهاى هيدرويرايمينَ شده شئن

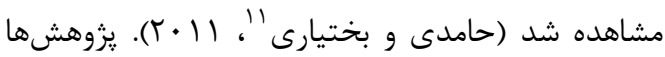

\footnotetext{
${ }^{7}$ Windauer

${ }^{8}$ Bewley

${ }^{9}$ Farooq

${ }^{10}$ Harris

${ }^{11}$ Hamedi and Bakhtiari
}

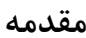

بقولات يس از غلات، از مهمترين محصولات زراعى

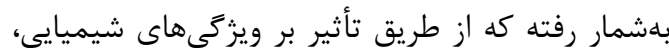

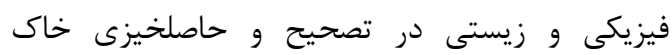

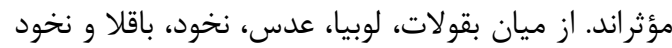
فرنكى بيشترين حساسيت نسبت به تيمار شورى را دارا

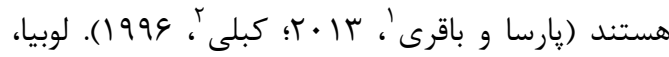
كياهى يكساله، علفى، دوليه و از خانواده بقولات بولئه

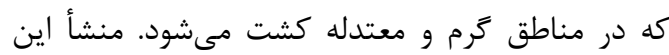

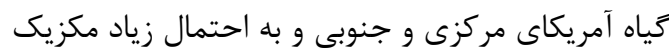
است (سميعى"، .... (Y). تنشهاى غير زيستى بر جنبههاى مختلف رشد

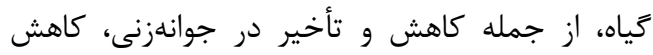
سرعت نمو، كاهش رشد اندامهاى كياهى، كاهش طول دوران رشد كياه و در نهايت كاهش توليد ماده خشك

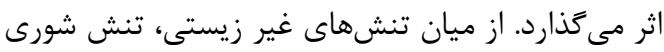

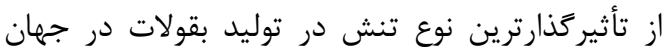

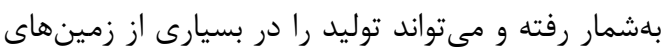

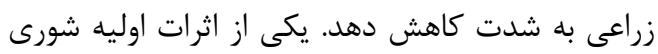

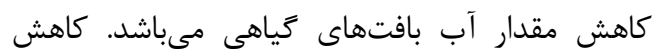

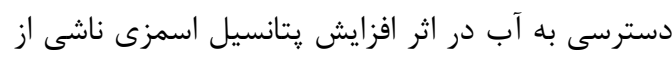

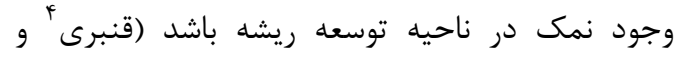

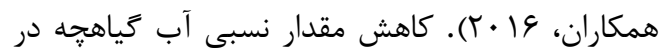
نتيجه تنش شورى مىتواند باعث تجمع انواع كونههاى

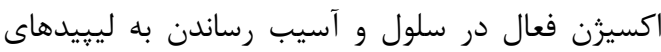

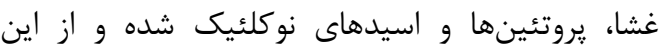
طريق مىتواند ويزگگىهايى نظير درصد جوانهزنى، وزن

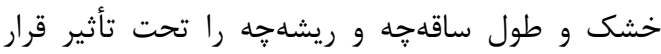

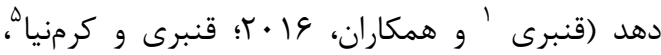

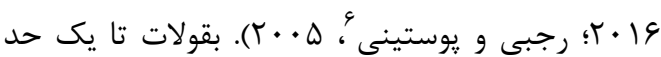

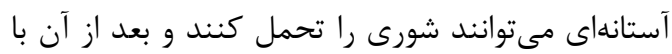

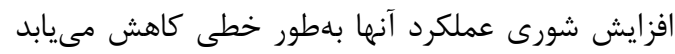

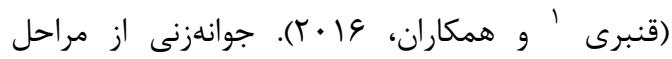

\footnotetext{
${ }^{1}$ Parsa and Bagheri

${ }^{2}$ Cobley

${ }^{3}$ Samiei

${ }^{4}$ Ghanbari

${ }^{5}$ Ghanbari and Karamnia

${ }^{6}$ Rajabi and Postini
} 
دانشكده علوم كشاورزى دانشكاه تربيت مدرس در سال بوجا انجام شد. تيمارهاى آزمايشى شامل دو تيمار

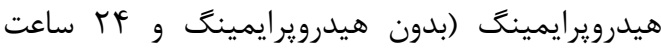

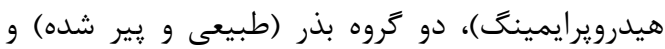

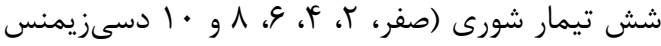
1. بر متر) بود. قبل از اجراى آزمايش بذرها با محلول

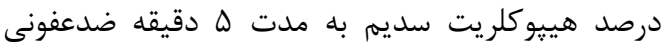

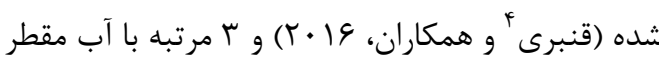

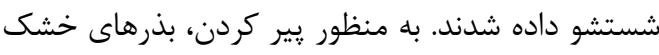

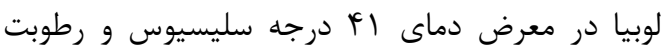

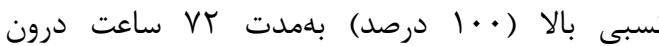
دسيكاتور در آون قرار داده شدند. همجنين براى درائ

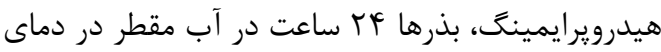
TD درجه سليسيوس (دماى اتاق) خيسانده شدند.

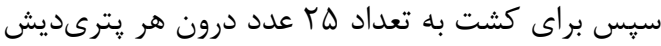

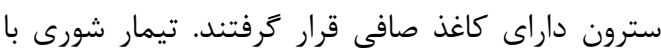
استفاده از NaCl خالص مرك، مطابق رابطه زير ايجاد

$$
\text { (1) (1ابطه }
$$

$$
T D S=640 \times E C
$$

كه در آن TDS، ميزان نمك خالص بر حسب گرم بر ليتر و EC ميزان هدايت الكتريكى بر حسب دسى دهى

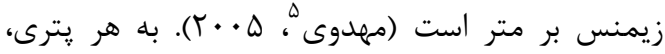

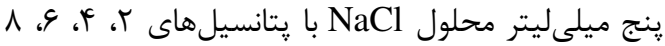
دسىزيمنس بر متر و براى يتانسيل صفر دسىزيمنس

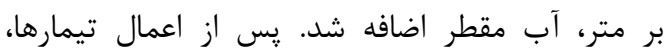

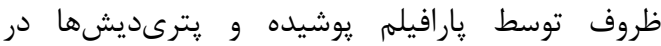

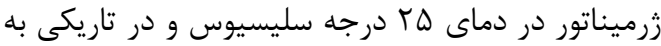

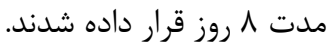

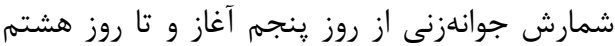

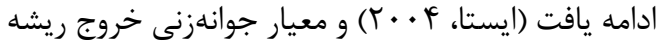

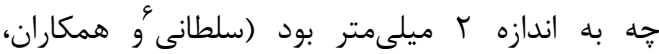

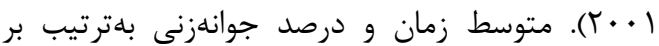

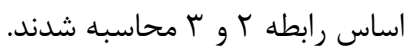

$$
\begin{aligned}
& \text { رابطه (r) }
\end{aligned}
$$

${ }^{4}$ Ghanbari

${ }^{5}$ Mahdavi

${ }^{6}$ Soltani
در زمينه تأثير يِيرى بذر و تنش شورى بر ويزگى هاى

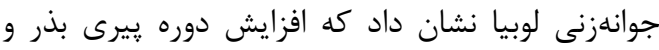
افزايش سطوح تنش شورى بر خصوصيات جوانهزنى لوبيا تأثير منفى كذاشته و از طريق تأثير بر روابط آبى كياه، سميت ناشى از تجمع يون، كاهش يلاسمايى، تغيير ساختمان مولكولى اسيدهاى نوكلئيك و كاهش فعاليت آنزيمها در نهايت موجب افت شاخصهاى نوائ نوانهزنى كرديد (قنبرى و كرمنيا، 19 • (T). طبق تعريف انجمن بينالمللى آزمون بذر به كليه

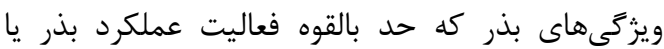
تودههاى بذرى را در حين جوانهزنى و سبز شدن كياهجه در دامنه گسترداى از شرايط محيطى تعيين

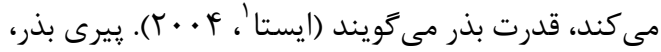
فر آيندى غير قابل بازَشت است. در اين فرآيند، كيفيت

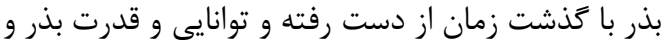
به دنبال آن ظرفيت و سرعت جوانهزنى براى زنده زند ماند كاهش مىدهد، ولى مىتوان با حفاظت بذر در شرايط

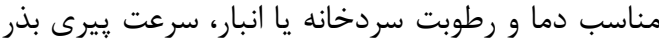

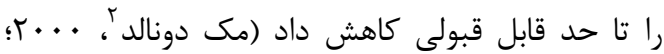

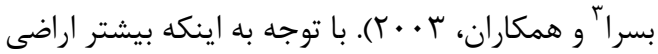
كشور ما شور هستند و لوبيا كياهى حساس به شورى است، همجنين به دليل انباردارى بذرهاى اين كَياه براى كشت بعد از كندم در خيلى از استانها با مشكل مواجه

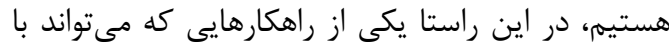

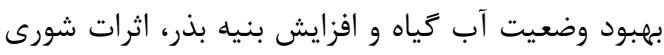
و زوال بذر را تعديل نمايد هيدرويرايمينگ است، اين اين

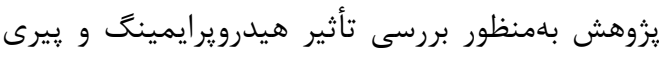

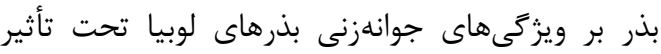

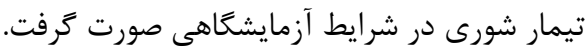

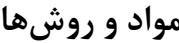

بلمنظور ارزيابى تأثير تيمار شورى، هيدرويرايمينَ

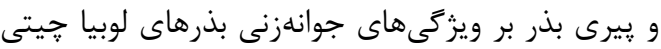
رقم صدرى، آزمايشى بلصورت فاكتوريل، در قالب طرح

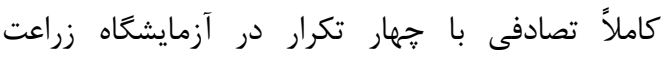

\footnotetext{
${ }^{1}$ ISTA

${ }^{2}$ McDonald

${ }^{3}$ Basra
} 
شد. براى مقايسه ميانكَينها از آزمون توكى در سطح آمارى يك درصد استفاده شد.

نتايج و بحث

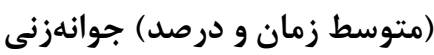

تجزيه واريانس دادهها نشان داد كه متوسط زمان و و ونوان درصد جوانهزنى از نظر شورى، يرايمينگ و برهمكنش دارهان

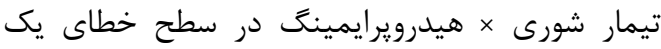

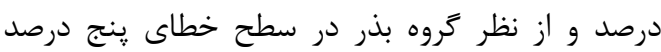
معنى دار است (جدول (). مقايسه متوسط زمان و درصد بدر درد

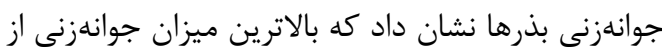
نظر كروه بذر در بذرهاى طبيعى مشاهده شد (بسأ

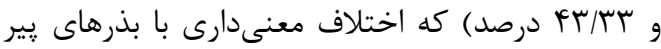
شده نداشت (جدول r). با توجه به معنىدار بودن

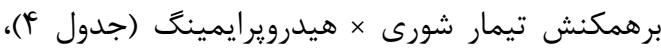

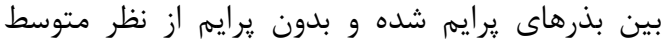

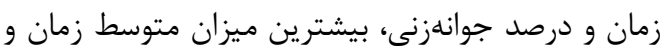
درصد جوانهزنى در تيمار شاهد (آب مقطر) و بذريز بذران

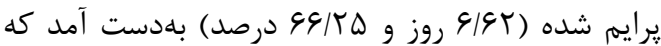

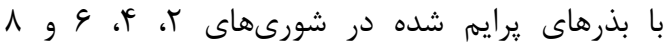
دسىزيمنس بر متر تفاوت معنى دارى نداشت و كمترين

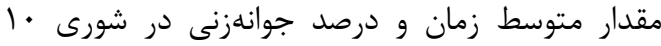

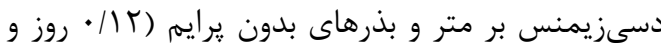

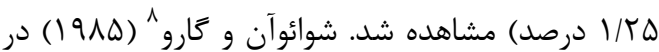
بررسى متوسط زمان و درصد جوانهزنى بذرهاى جو و ودان نخود فرنكى دريافتند كه بذرهاى جو قادراند تا تيمار شورى / T/Q دسىزيمنس بر متر همانند تيمار شاهد خود جوانهزنى داشته باشند، اين در حالى است كه متر متوسط زمان و درصد جوانهزنى بذرهاى نخود فرنكى با افزايش

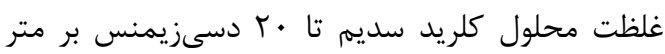

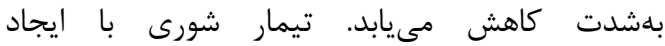
يتانسيلهاى بالاى اسمزى از جذب آب توسط كياهحه

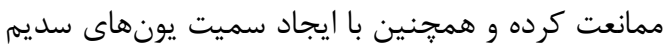
و كلر در گياهجه بر متوسط زمان و درصد جوانهزنى اثر

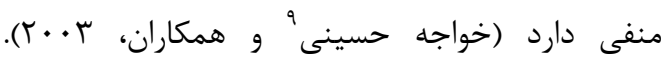

\footnotetext{
${ }^{8}$ Shoeoan and Garo
}

${ }^{9}$ Khajeh-Hosseini
در اين فرمول D تعداد روزها پِ از شروع آزمون جوانهزنى، SN كل تعداد بذرهاى جوانه زده و N إن تعداد بذرهاى جوانه زده در روز D است (اليس' و و همكاران، . (191. رابطه (T)

$$
P G=N_{i} / N \times 100
$$

در آن N $N_{i}$ تعداد بذر جوانه زده شده تا روز هشتم و

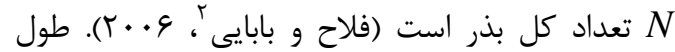
ريشه קه و ساقهجه با خطكش ميلىمترى اندازهيرى

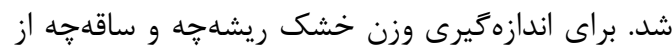

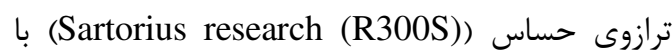

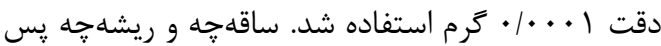

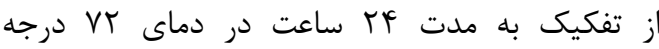

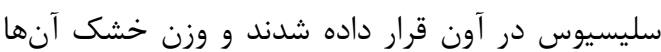

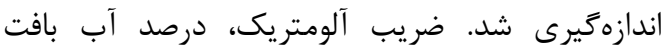

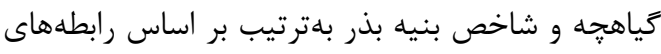
ه، أ أو 9 محاسبه شدند.

$$
\begin{aligned}
& \text { رابطه (F) وزن خشك ساقه جه }
\end{aligned}
$$

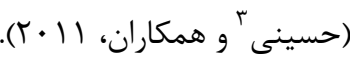

$$
\begin{aligned}
& \text { رابطه (ه) = درصد آب بافت زياهحه }
\end{aligned}
$$

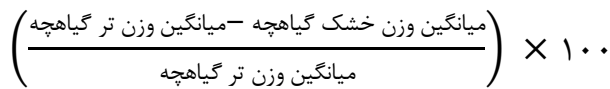

$$
\begin{aligned}
& \text { (فولر و و همكاران، (191) (19). } \\
& \text { رابطه (ع) }
\end{aligned}
$$

X درصد نهايى جوانه زنى = شاخص بنيه بذر طول كياهجه

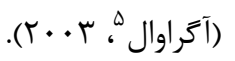

جهت تعيين فعاليت آنزيمهاى آلفا و بتا آميلاز از

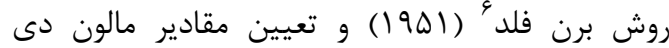

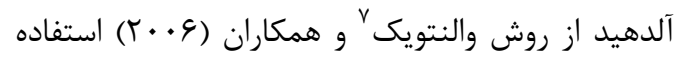
شد. دادهها با استفاده از نرمافزار SAS نسخه ك/

\footnotetext{
${ }^{1}$ Ellis

${ }^{2}$ Fallah and Babaei

${ }^{3}$ Hosseini

${ }^{4}$ Fowler

${ }^{5}$ Agrawal

${ }^{6}$ Bernfeld

${ }^{7}$ Valentovic
} 
شد كه با بذر طبيعى يرايم شده تفاوت معنىدارى

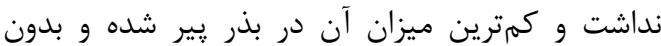

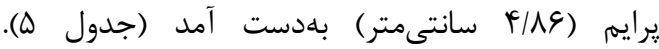

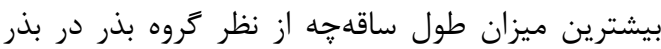

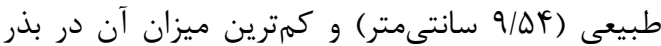

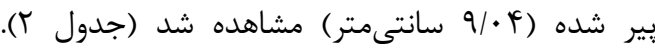

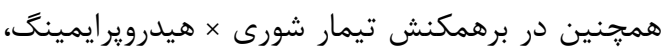
بيشترين ميزان طول ساقهجه در تيمار شاهد (آب

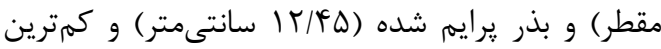

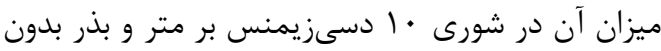
يرايم (T/FF سانتىمتر) مشاهده شد. نتايج بررسى اثر دما و شورى بر طول ريشه جه و ساقهجه شبدر برسيم نشان داد كه با افزايش سطوح شورى درى در هر دو سطح دمايى، طول ريشهجه و ساقهجه كاهش يافته و بيشترين طول ريشهجه و ساقهجه در تيمار شاهد و كمترين آن در شورى Ir الدسىزيمنس بر متر مشاهد شد (طويلىه

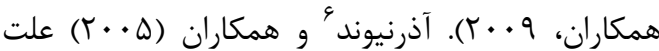
كاهش طول ريشهجه و ساقهجه در اثر افزايش سطوح

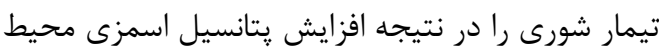

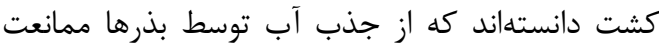

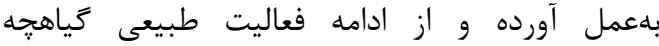

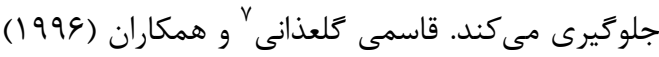
در تحقيقات خود روى تأثير فرسودىى و زوال بذر مانى دران

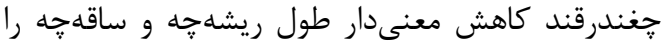

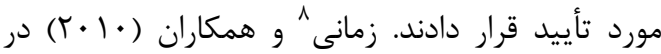

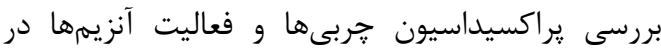
بذرهاى يُير شده گلرنخ اظهار داشتند كه رابطه بين

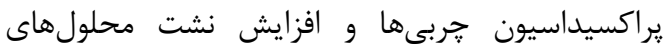
الكتروليت در اثر تخريب ساختار غشاى سيتويلاسمى موجب كاهش طول ريشه קه و ساقه קه كرديده است.

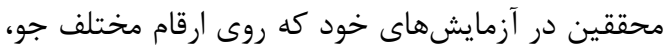

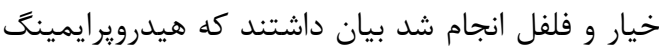
موجب افزايش طول ريشه קه و ساقهجه گرديد (جودى

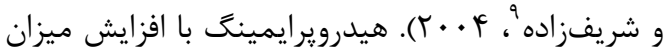

\footnotetext{
${ }^{5}$ Tavili

${ }^{6}$ Azarnivand

${ }^{7}$ Ghasemi Golazani

${ }^{8}$ Zamani

${ }^{9}$ Judi and Sharifzadeh
}

احمدلو' و همكاران (Y| • (Y) در آزمايشهاى خود دريافتند كه يِيرى بذر بر متوسط زمان و درصد

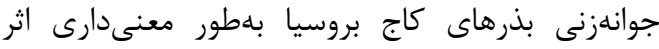

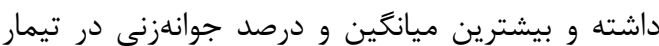
شاهد و كمترين آن در تيمار و9 ساعت ييرى مشاهده

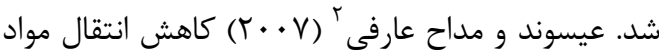
تجزيه شده از بافت ذخيرهاى بذر به محور جنين و و كند

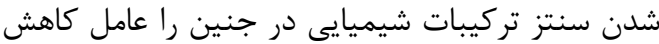
ميانگين و درصد جوانهزنى بذرها دانستهاند. تحقيقات

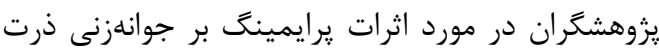
شيرين تحت تيمار شورى نشان داد كه هيدرويرايمينگ مؤلفههاى جوانهزنى را تحت شرايط تيمار شورى بهبود

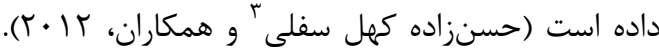
بهبود متوسط زمان و درصد جوانهزنى در بذرهاى يرايم شده ممكن است ناشى از برهمكنش بين راديكالهاى

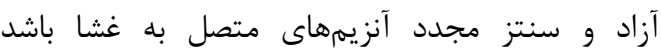

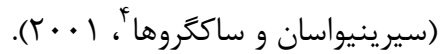

طول (ريشه جه و ساقه جدول ا نشان مىدهد كه طول ريشهجه از نظر تيمار شورى، هيدرويرايمينَ و برهمكنش تيمار شورى بكروه بذر در سطح احتمال خطاى يك درصد و برهمكنش

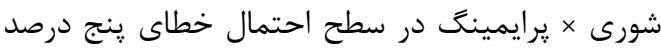

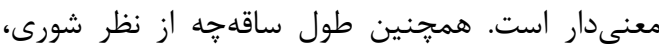
گروه بذر و يرايمينَ در سطح احتمال خطاى يك درصد و برهمكنش تيمار شورى × هيدرويرايمينگ در

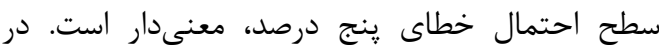
برهمكنش تيمار شورى×كروه بذر بيشترين ميزان طول

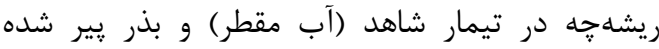

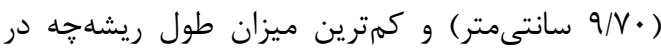
شورى • ا دسى زيمنس بر متر و بذر طبيعى (V/V)

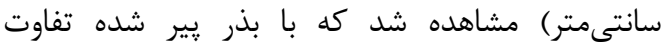

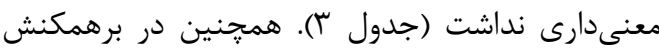

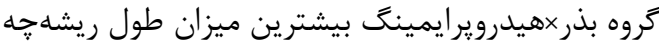
در بذر يير شده و يرايم شده (4 \&/4 سانتىمتر) مشاهده

\footnotetext{
${ }^{1}$ Ahmadloo

${ }^{2}$ Eisvand and Madah Arefi

${ }^{3}$ Hassan zadeh Kahal Sofla

${ }^{4}$ Srinivasan and Saxena
} 
جوانهزنى جهار زنوتيٍ جوى بدون يوشينه گزارش كردند كه افزايش سطوح تيمار شورى موجب كاهش وزن خشك ريشه קه و ساقه קه كرديده و در غلظت سراء مولار كاهش بسيار معنى دارى در اين صفات مشاهده

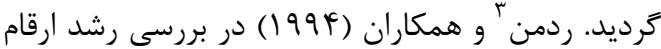
مختلف كلزاى تراريخته و استاندارد در راسخ به به تيمار شورى دريافتند كه كاهش يتانسيل اسمزى و ايجاد سميت يونى ناشى از افزايش سطوح تيمار شورى موجب

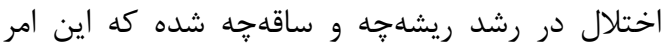
كاهش وزن خشك كياهجه را بهدنبال دارد. يزوهشكران با بررسى تأثير يرايمينح بر تغييرات خصوصيات جوانهزنى و رشد كياهجه برنج بيان داشتند كه افزايش سطوح

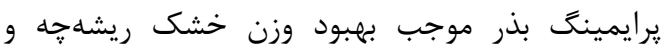

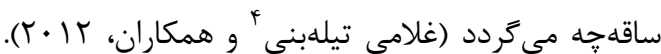
يزوهشها در زمينه برايمينگ بذرهاى خربزه نشان دان داد

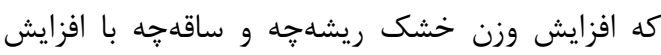
سطوح هيدرويرايمينگ مىتواند ناشى از افزايش سنتز

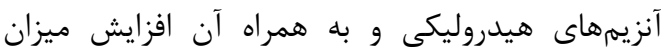

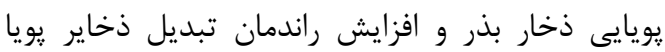

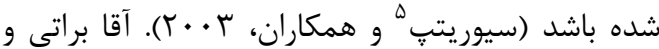

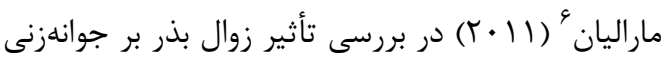

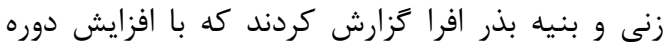

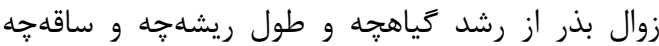

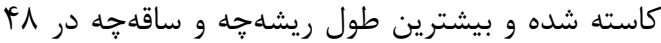

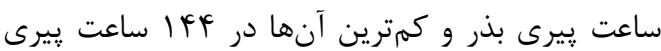

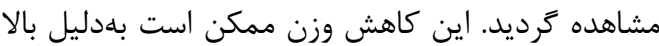
رفتن رطوبت نسبى و دما در بذرها و مركى گياهحه تحت

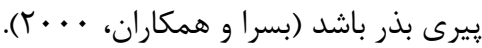

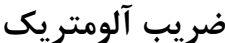

جدول ا نشان داد كه ضريب آلومتريك در تيمار

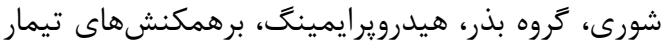

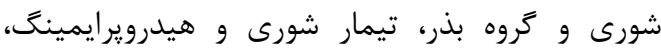

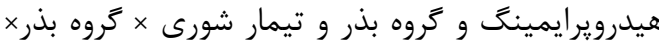
هيدرويرايمينَ در سطح احتمال خطاى يك درصد

\footnotetext{
${ }^{3}$ Redmann

${ }^{4}$ Gholami Tileh Boni

${ }^{5}$ Sivritepe

${ }^{6}$ Aghabarati and Maralian
}

آنزيمهاى آميلاز و ساكارز سنتاز در ريشهجه و ساقهجه موجب افزايش ميزان طول آنها شده كه اين امر به

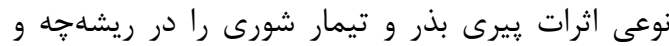

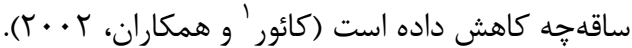

\section{وزن خشك (ريشه جه و ساقه جه )} جدول ا نشان داد كه وزن خشك ريشه جه از نظر تيمار شورى، گروه بذر، هيدرويرايمينگ، برهمكنش دهاى داى تيمار شورى × هيدرويرايمينَ، هيدرويرايمينَ × گَروه

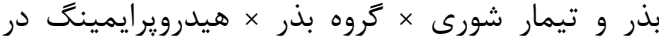
سطح احتمال خطاى يك درصد معنى دار است (جدول (). همجنين وزن خشك ساقهجه از نظر تيمار شورى،

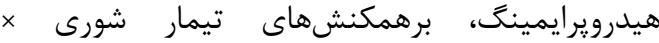

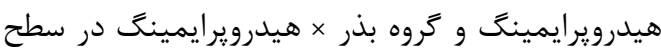
احتمال خطاى يك درصد و گروه بذر و برهمكنش تيمار شورى × گروه بذر در سطح احتمال خطاى ينج درصد

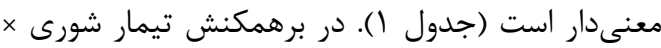

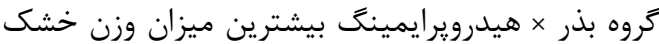

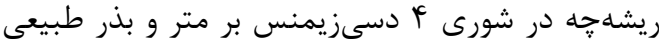

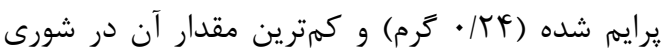

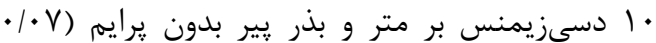

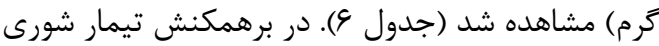

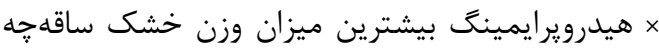
در شورى •ا دسىزيمنس بر متر و بذر ير يرايم شده د

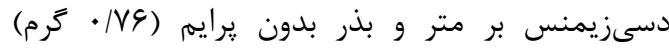

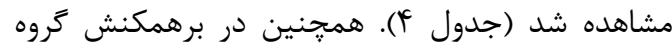
بذر و هيدرويرايمينَ بيشترين ميزان وزن خشك الند

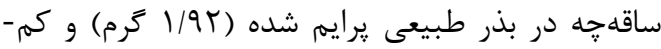
ترين مقدار آن در بذر بير بدون يرايم (1/ • • كرم) وجود

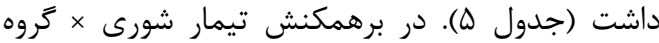
بذر بيشترين ميزان وزن خشك ساقهاه در شورى دسىزيمنس بر متر و بذر طبيعى (19/9 كرم) و كمترين

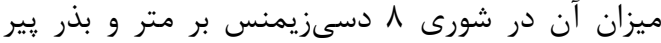

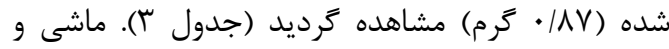

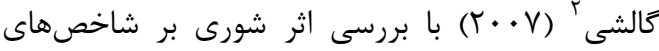

\footnotetext{
${ }^{1}$ Kaur

${ }^{2}$ Mashi and Galeshi
} 


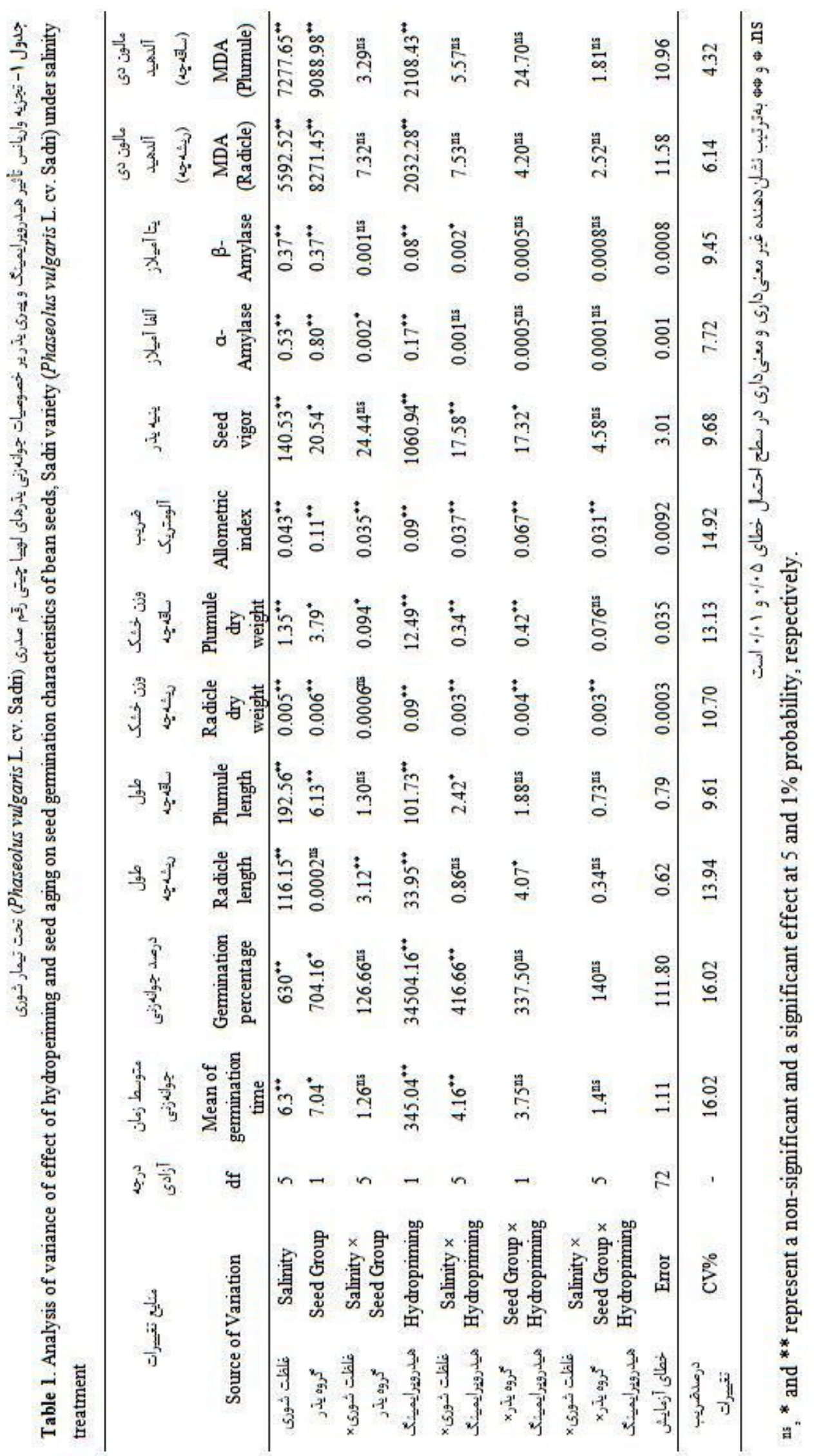


جدول r- تأثير تيمار شورى، كروه بذر و هيدرويرايمينگ بر ميانكين صفات مختلف جوانهزنى بذرهاى لوبيا جيتى، رقم صدرى

Table 2. The effect of salinity treatment, seed group and hydropriming on average germination characteristics of bean seeds, Sadri cultivar

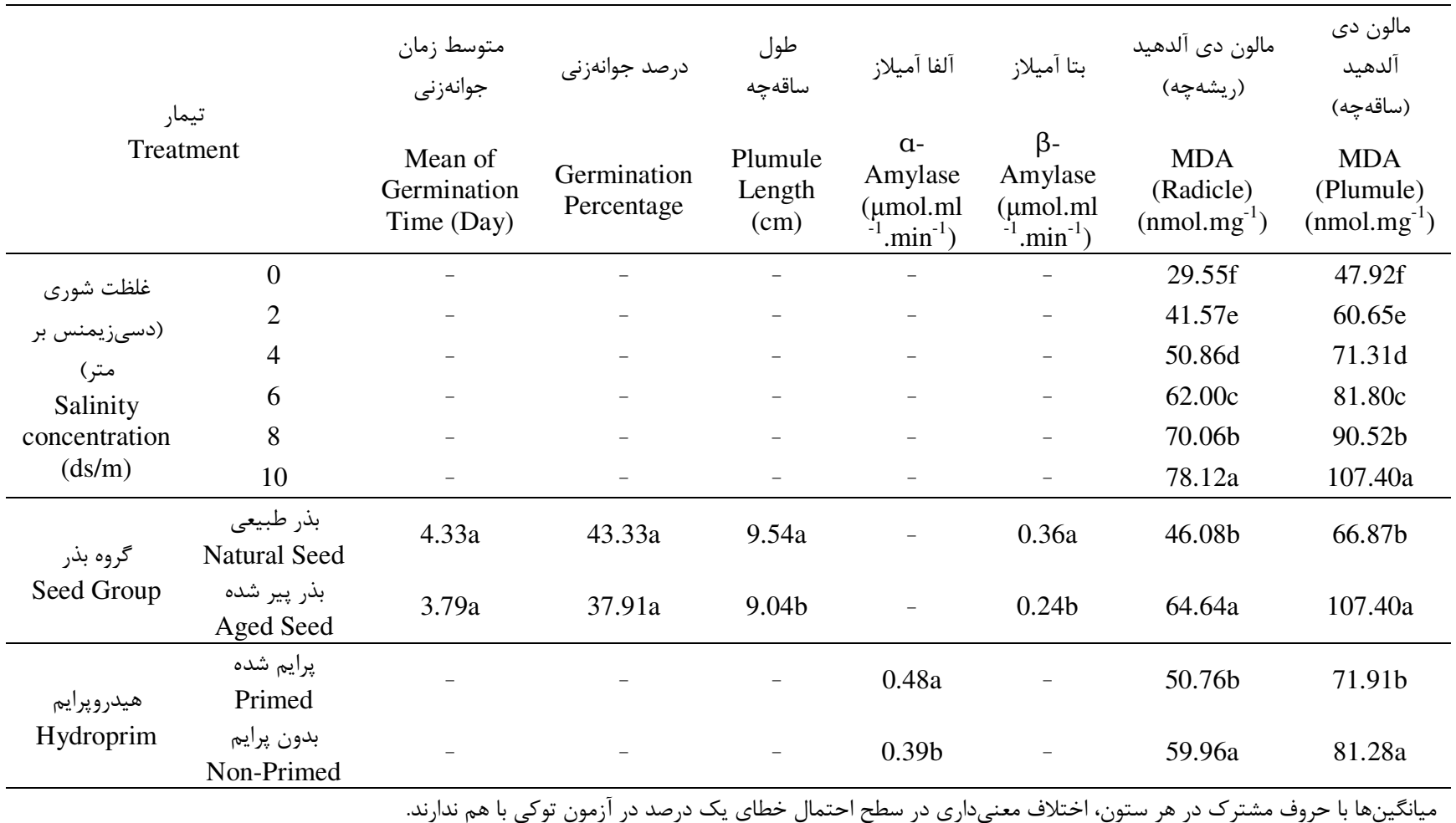

The means with the same letters in each column do not have a significant difference at the probability level of $1 \%$ in the Tukey Test.

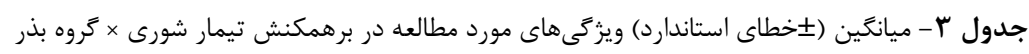

Table 3. Mean ( \pm standard error) characteristics studied in the interaction of salinity treatment $\times$ seed group

\begin{tabular}{|c|c|c|c|c|}
\hline $\begin{array}{c}\text { غلظت شورى } \\
\text { (دسىزيمنس بر متر) } \\
\text { Salinity concentration } \\
\text { (ds/m) }\end{array}$ & Seed Group & $\begin{array}{l}\qquad \begin{array}{l}\text { طول ريشه } \\
\text { Radicle Length } \\
\text { (سانتىمتر) }\end{array} \\
\text { (cm) }\end{array}$ & $\begin{array}{c}\text { وزن خشك ساقه } \text { (كرم) } \\
\text { Plumule Dry Weight } \\
\text { (g) }\end{array}$ & $\begin{array}{c}\text { آلفا آميلاز } \\
\text { آميكرو مول بر ميلىليتر بر دقيقه) } \\
\text { a-Amylase } \\
\left(\mu \mathrm{mol} . \mathrm{ml}^{-1} . \mathrm{min}^{-1}\right)\end{array}$ \\
\hline \multirow{2}{*}{0} & Natural Seed & $8.24 \pm 0.55 \mathrm{a}$ & $1.42 \pm 0.21 \mathrm{cde}$ & $0.79 \pm 0.03 \mathrm{a}$ \\
\hline & Aged Seed & $9.70 \pm 0.56 \mathrm{~b}$ & $0.90 \pm 0.24 \mathrm{~g}$ & $0.56 \pm 0.03 \mathrm{c}$ \\
\hline \multirow{2}{*}{2} & Natural Seed & $8.59 \pm 0.50 \mathrm{~b}$ & $1.38 \pm 0.13 \mathrm{de}$ & $0.68 \pm 0.02 b$ \\
\hline & Aged Seed & $8.30 \pm 0.90 b$ & $1.10 \pm 0.12 \mathrm{f}$ & $0.49 \pm 0.02 \mathrm{~d}$ \\
\hline \multirow{2}{*}{4} & Natural Seed & $6.34 \pm 0.38 \mathrm{c}$ & $1.56 \pm 0.18 \mathrm{bcd}$ & $0.57 \pm 0.03 \mathrm{c}$ \\
\hline & Aged Seed & $6.32 \pm 0.45 \mathrm{c}$ & $1.27 \pm 0.31 \mathrm{ef}$ & $0.39 \pm 0.02 \mathrm{e}$ \\
\hline \multirow{2}{*}{6} & Natural Seed & $3.98 \pm 0.31 \mathrm{de}$ & $1.96 \pm 0.04 \mathrm{a}$ & $0.47 \pm 0.02 \mathrm{~d}$ \\
\hline & Aged Seed & $3.44 \pm 0.40 \mathrm{e}$ & $1.59 \pm 0.18 \mathrm{bc}$ & $0.31 \pm 0.02 \mathrm{f}$ \\
\hline \multirow{2}{*}{8} & Natural Seed & $4.71 \pm 0.41 \mathrm{~d}$ & $1.52 \pm 0.20 \mathrm{bcd}$ & $0.37 \pm 0.02 \mathrm{e}$ \\
\hline & Aged Seed & $3.68 \pm 0.36 \mathrm{e}$ & $0.87 \pm 0.28 \mathrm{~g}$ & $0.19 \pm 0.02 \mathrm{~h}$ \\
\hline \multirow{2}{*}{10} & Natural Seed & $2.07 \pm 0.25 \mathrm{f}$ & $1.95 \pm 0.32 \mathrm{a}$ & $0.28 \pm 0.02 \mathrm{~g}$ \\
\hline & Aged Seed & $2.53 \pm 0.70 \mathrm{f}$ & $1.66 \pm 0.30 \mathrm{~b}$ & $0.10 \pm 0.01 \mathrm{i}$ \\
\hline
\end{tabular}

The means with the same letters in each column do not have a significant difference in the probability level of $1 \%$ error in the Tukey Test. 


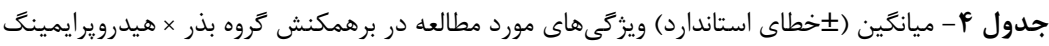

Table 4. Mean ( \pm standard error) characteristics studied in the interaction of seed group $\times$ hydropriming

\begin{tabular}{|c|c|c|c|c|}
\hline كروه بذر & هيدرويرايمينگ & طول ريشه جه (سانتىمتر) & وزن خشك ساقهجه (كرم) & بنيه بذر \\
\hline Seed group & Hydropriming & $\begin{array}{l}\text { Radicle length } \\
(\mathrm{cm})\end{array}$ & $\begin{array}{l}\text { Plumule dry weight } \\
(\mathrm{g})\end{array}$ & Seed vigor \\
\hline بذر طبيعى & Primed & $6.05 \pm 1.26 \mathrm{a}$ & $1.92 \pm 0.17 \mathrm{a}$ & $9.94 \pm 3.90 \mathrm{a}$ \\
\hline Natural Seed & non-Primed & $5.28 \pm 1.19 \mathrm{~b}$ & $1.34 \pm 0.16 \mathrm{c}$ & $4.14 \pm 2.77 \mathrm{~b}$ \\
\hline بذر يِير شده & Primed & $6.46 \pm 1.44 \mathrm{a}$ & $1.66 \pm 0.18 \mathrm{~b}$ & $9.86 \pm 4.34 \mathrm{a}$ \\
\hline Aged Seed & non-Primed & $4.86 \pm 1.38 \mathrm{~b}$ & $0.81 \pm 0.18 \mathrm{~d}$ & $2.37 \pm 1.87 \mathrm{c}$ \\
\hline
\end{tabular}

The means with the same letters in each column do not have a significant difference in the probability level of $1 \%$ error in the Tukey Test.

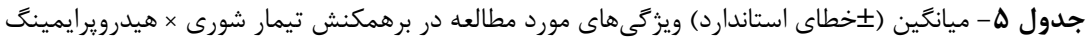

Table 5. Mean ( \pm standard error) characteristics studied in the interaction of salinity treatment $\times$ hydropriming

\begin{tabular}{|c|c|c|c|c|c|c|c|}
\hline غلظت شورى & هيدرويرايمينَ & متوسط زمان & درصد جوانهزنى & طول ساقه & وزن خشك & بنيه بذر & بتا آميلاز \\
\hline $\begin{array}{c}\text { Salinity } \\
\text { concentration } \\
(\mathrm{ds} / \mathrm{m})\end{array}$ & Hydropriming & $\begin{array}{c}\text { Mean of } \\
\text { germination } \\
\text { time (day) }\end{array}$ & $\begin{array}{c}\text { Germination } \\
\text { percent }\end{array}$ & $\begin{array}{l}\text { Plumule } \\
\text { length }(\mathrm{cm})\end{array}$ & $\begin{array}{c}\text { Plumule } \\
\text { dry weight } \\
\text { (g) }\end{array}$ & Seed vigor & $\begin{array}{c}\text { B-amylase } \\
\left(\mu \mathrm{mol} \cdot \mathrm{ml}^{-}\right. \\
\left.{ }^{1} \cdot \mathrm{min}^{-1}\right)\end{array}$ \\
\hline \multirow{2}{*}{0} & Primed & $6.62 \pm 0.45 \mathrm{a}$ & $66.25 \pm 4.58 \mathrm{a}$ & $12.45 \pm 0.58 b c$ & $1.48 \pm 0.15 \mathrm{c}$ & $14.44 \pm 2.36 \mathrm{a}$ & $0.58 \pm 0.03 \mathrm{a}$ \\
\hline & non-Primed & $3.00 \pm 0.65 b c$ & $30.00 \pm 6.54 b c$ & $11.62 \pm 0.39 \mathrm{c}$ & $0.83 \pm 0.24 \mathrm{ef}$ & $5.97 \pm 2.40 \mathrm{de}$ & $0.47 \pm 0.03 \mathrm{~b}$ \\
\hline \multirow{2}{*}{2} & Primed & $5.57 \pm 0.51 \mathrm{a}$ & $57.50 \pm 5.17 \mathrm{a}$ & $14.92 \pm 0.46 \mathrm{a}$ & $1.47 \pm 0.09 \mathrm{c}$ & $14.03 \pm 2.72 \mathrm{a}$ & $0.45 \pm 0.03 \mathrm{~b}$ \\
\hline & non-Primed & $2.37 \pm 0.45 b c$ & $23.75 \pm 4.58 b c$ & $12.30 \pm 0.53 b c$ & $1.75 \pm 0.37 \mathrm{e}$ & $4.79 \pm 2.03 \mathrm{efg}$ & $0.38 \pm 0.04 \mathrm{c}$ \\
\hline \multirow{2}{*}{4} & Primed & $5.75 \pm 0.58 \mathrm{a}$ & $57.50 \pm 5.82 \mathrm{a}$ & $12.57 \pm 0.44 \mathrm{~b}$ & $1.86 \pm 0.04 \mathrm{~b}$ & $11.19 \pm 2.29 \mathrm{~b}$ & $0.37 \pm 0.04 \mathrm{c}$ \\
\hline & non-Primed & $2.37 \pm 0.65 b c$ & $23.75 \pm 6.51 b c$ & $9.55 \pm 0.43 \mathrm{~d}$ & $0.98 \pm 0.17 \mathrm{e}$ & $3.62 \pm 1.98 \mathrm{fgh}$ & $0.31 \pm 0.03 \mathrm{~d}$ \\
\hline \multirow{2}{*}{6} & Primed & $5.75 \pm 0.51 \mathrm{a}$ & $57.50 \pm 5.17 \mathrm{a}$ & $8.14 \pm 0.54 \mathrm{e}$ & $1.94 \pm 0.07 \mathrm{~b}$ & $7.13 \pm 1.74 \mathrm{~cd}$ & $0.26 \pm 0.03 \mathrm{e}$ \\
\hline & non-Primed & $3.12 \pm 0.62 \mathrm{~b}$ & $31.25 \pm 6.23 \mathrm{~b}$ & $6.57 \pm 0.34 \mathrm{f}$ & $1.60 \pm 0.18 \mathrm{c}$ & $3.05 \pm 1.14 \mathrm{gh}$ & $0.20 \pm 0.03 \mathrm{f}$ \\
\hline \multirow{2}{*}{8} & Primed & $6.12 \pm 0.49 \mathrm{a}$ & $61.25 \pm 4.95 \mathrm{a}$ & $8.19 \pm 0.46 \mathrm{e}$ & $1.63 \pm 0.16 \mathrm{c}$ & $7.82 \pm 1.35 \mathrm{c}$ & $0.19 \pm 0.03 \mathrm{f}$ \\
\hline & non-Primed & $2.00 \pm 0.70 \mathrm{c}$ & $20.00 \pm 7.07 \mathrm{c}$ & $6.10 \pm 0.43 \mathrm{f}$ & $0.76 \pm 0.22 \mathrm{f}$ & $2.02 \pm 1.58 \mathrm{~h}$ & $0.15 \pm 0.03 \mathrm{~g}$ \\
\hline \multirow{2}{*}{10} & Primed & $5.75 \pm 0.64 \mathrm{a}$ & $57.50 \pm 6.40 \mathrm{a}$ & $5.56 \pm 0.55 \mathrm{~g}$ & $2.37 \pm 0.12 \mathrm{a}$ & $4.80 \pm 0.75$ ef & $0.14 \pm 0.03 \mathrm{gh}$ \\
\hline & non-Primed & $0.12 \pm 0.19 \mathrm{~d}$ & $1.25 \pm 1.76 \mathrm{~d}$ & $3.44 \pm 0.44 \mathrm{~h}$ & $1.24 \pm 0.10 \mathrm{~d}$ & $0.08 \pm 0.23 \mathrm{i}$ & $0.12 \pm 0.03 \mathrm{~h}$ \\
\hline
\end{tabular}

The means with the same letters in each column do not have a significant difference in the probability level of $1 \%$ error in the Tukey Test.

$$
\begin{aligned}
& \text { است. هر جند كه اين نسبت تحت كنترل عوامل زنتيكى } \\
& \text { معنى دار است (جدول (). در برهمكنش تيمار شورى × } \\
& \text { است ولى تا حدودى تحت تأثير عوامل محيطى نيز قرار } \\
& \text { دارد (كوجكى و ظريف كتابى ! 1999). } \\
& \text { گروه بذر × هيدرويرايمينگ بيشترين ميزان ضريب }
\end{aligned}
$$

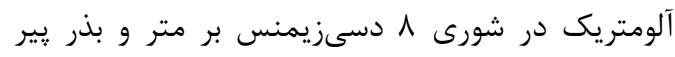

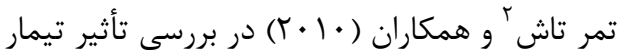

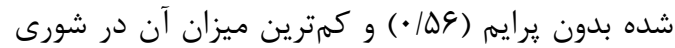

$$
\begin{aligned}
& \text { شورى و خشكى بر ويزگى هاى جوانهزنى شبدر برسيم } \\
& \text { • ا دسىزيمنس بر متر و بذر طبيعى يرايم شده (9 •|•) } \\
& \text { ززارش كردند كه بين همه تيمارها از لحاظ ضريب } \\
& \text { آلومتريك اختلاف معنىدارى وجود داشته و بيشترين } \\
& \text { ضريب آلومتريك متعلق به تيمار · إيلى مولار تيمار } \\
& \text { مشاهده شد كه بجز از تيمار شاهد و بذر پيير شده بدون }
\end{aligned}
$$

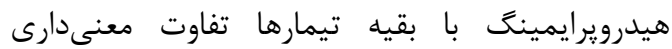

$$
\begin{aligned}
& \text { نداشت (جدول ع). } \\
& \text { نسبت وزن خشك ريشه جه به وزن خشك ساقه } \\
& { }^{1} \text { Koocheki and Zarif Ketabi } \\
& 2 \text { Tamartash } \\
& \text { بيانگر نوعى مكانيسم تحمل نسبت به تنشهاى محيطى }
\end{aligned}
$$




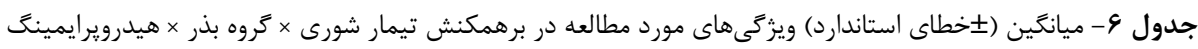

Table 6. Mean ( \pm standard error) characteristics studied in the interaction of salinity $\times$ treatment seed group $\times$ hydropriming

\begin{tabular}{|c|c|c|c|c|}
\hline $\begin{array}{c}\text { غلظت شورى } \\
\text { Salinity concentration } \\
\end{array}$ & $\begin{array}{c}\text { كروه بذر } \\
\text { Seed group } \\
\end{array}$ & $\begin{array}{l}\text { هيدرويرايمينگ } \\
\text { Hydropriming }\end{array}$ & $\begin{array}{l}\text { وزن خشك ريشه جه (كرم) } \\
\text { Radicle dry weight (g) }\end{array}$ & $\begin{array}{c}\text { ضريب آلومتريك } \\
\text { Allometric index } \\
\end{array}$ \\
\hline \multirow{4}{*}{$\begin{array}{c}\text { آب مقطر } \\
\mathrm{EC}=0 \mathrm{ds} / \mathrm{m}\end{array}$} & بذر طبيعى & Primed & $0.18 \pm 0.00$ efg & $0.11 \pm 0.01 \mathrm{c}$ \\
\hline & Natural Seed & non-Primed & $0.12 \pm 0.0 \mathrm{jk}$ & $0.10 \pm 0.00 \mathrm{c}$ \\
\hline & بذر پير شده & Primed & $0.17 \pm 0.00$ efgh & $0.13 \pm 0.00 \mathrm{c}$ \\
\hline & Aged Seed & non-Primed & $0.13 \pm 0.01 \mathrm{ij}$ & $0.35 \pm 0.11 \mathrm{~b}$ \\
\hline \multirow{4}{*}{ r دسىزيمنس بر متر } & بذر طبيعى & Primed & $0.23 \pm 0.01 \mathrm{ab}$ & $0.14 \pm 0.00 \mathrm{c}$ \\
\hline & Natural Seed & non-Primed & $0.15 \pm 0.00 \mathrm{hi}$ & $0.13 \pm 0.00 \mathrm{c}$ \\
\hline & بذر پير شده & Primed & $0.23 \pm 0.00 \mathrm{ab}$ & $0.17 \pm 0.00 \mathrm{c}$ \\
\hline & Aged Seed & non-Primed & $0.11 \pm 0.00 \mathrm{jk}$ & $0.13 \pm 0.00 \mathrm{c}$ \\
\hline \multirow{4}{*}{ 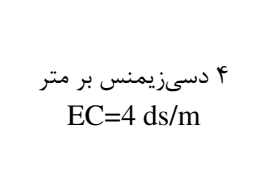 } & بذر طبيعى & Primed & $0.24 \pm 0.00 \mathrm{a}$ & $0.13 \pm 0.00 \mathrm{c}$ \\
\hline & Natural Seed & non-Primed & $0.12 \pm 0.00 \mathrm{jk}$ & $0.10 \mathrm{c} \pm 0.00$ \\
\hline & بذر پير شده & Primed & $0.19 \pm 0.00 \mathrm{def}$ & $0.10 \pm 0.00 \mathrm{c}$ \\
\hline & Aged Seed & non-Primed & $0.11 \pm 0.00 \mathrm{k}$ & $0.18 \pm 0.05 \mathrm{c}$ \\
\hline \multirow{4}{*}{ צ دسىزيمنس بر متر } & بذر طبيعى & Primed & $0.21 \pm 0.00 \mathrm{bcd}$ & $0.10 \pm 0.00 \mathrm{c}$ \\
\hline & Natural Seed & non-Primed & $0.19 \pm 0.00 \mathrm{cde}$ & $0.10 \pm 0.00 \mathrm{c}$ \\
\hline & بذر پير شده & Primed & $0.21 \pm 0.01 \mathrm{bc}$ & $0.11 \pm 0.00 \mathrm{c}$ \\
\hline & Aged Seed & non-Primed & $0.16 \pm 0.00$ ghi & $0.12 \pm 0.00 \mathrm{c}$ \\
\hline \multirow{4}{*}{ A دسىزيمنس بر متر } & بذر طبيعى & Primed & $0.18 \pm 0.00$ efgh & $0.09 \pm 0.00 \mathrm{c}$ \\
\hline & Natural Seed & non-Primed & $0.15 \pm 0.00 \mathrm{hi}$ & $0.13 \pm 0.00 \mathrm{c}$ \\
\hline & بذر پير شده & Primed & $0.17 \pm 0.01 \mathrm{efgh}$ & $0.13 \pm 0.01 \mathrm{c}$ \\
\hline & Aged Seed & non-Primed & $0.13 \pm 0.00 \mathrm{ij}$ & $0.56 \pm 0.19 a$ \\
\hline \multirow{4}{*}{ 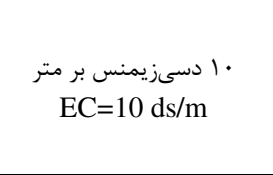 } & بذر طبيعى & Primed & $0.16 \pm 0.01 \mathrm{fgh}$ & $0.06 \pm 0.00 \mathrm{c}$ \\
\hline & Natural Seed & non-Primed & $0.16 \pm 0.00$ ghi & $0.11 \pm 0.00 \mathrm{c}$ \\
\hline & بذر پِير شده & Primed & $0.19 \pm 0.00$ cde & $0.09 \pm 0.00 \mathrm{c}$ \\
\hline & Aged Seed & non-Primed & $0.17 \pm 0.011$ & $0.06 \pm 0.00 \mathrm{c}$ \\
\hline
\end{tabular}
ميانكينها با حروف مشترك در هر ستون، اختلاف معنى دارى در سطح احتمال خطاى يك درصد در آزمون توكى با هم ندارند.

The means with the same letters in each column do not have a significant difference in the probability level of $1 \%$ error in the Tukey Test.

تنش را موجب مى گردد. در اين بين رشد ساقهجه در مقايسه

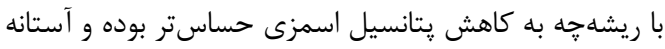

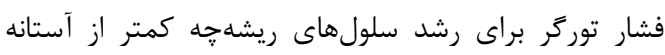
فشار تور گر براى رشد سلول هاى ساقهجه است (هايكينز و همكاران، ץ + . ץ)، در نتيجه مىتوان توصيف كرد كه با افزايش سطوح تيمار شورى ضريب آلومتريك افزايش

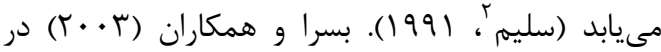
مطالعهاى بر روى بذر ينبه دريافتند كه افزايش سطوح ييرى بذر باعث كاهش رشد زياهجه شده و كاهش

\footnotetext{
${ }^{1}$ Hopkins

${ }^{2}$ Salim
}

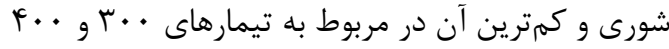

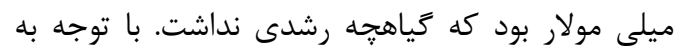

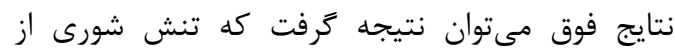

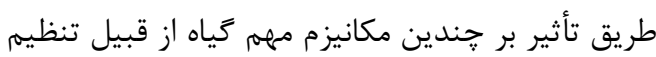

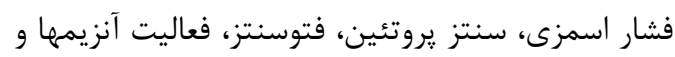

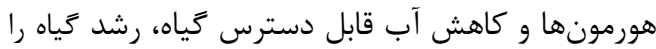

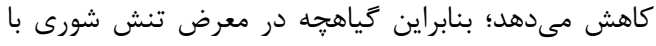

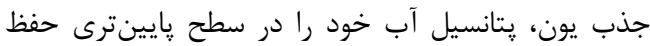

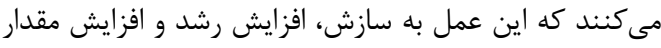

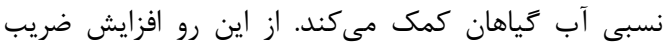

$$
\begin{aligned}
& \text { آلومتريك در سطوح بالاى تيمار شورى به دليل نقش مثبتى ابنى }
\end{aligned}
$$

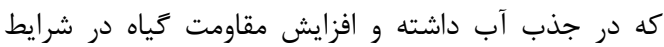


× هيدرويرايمينگ، بيشترين مقدار بنيه بذر در بذر

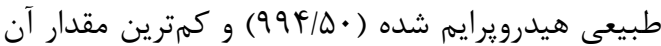

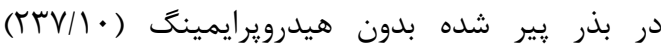

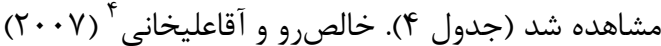
در بررسى اثر تيمار شورى و خشكى بر جوانهزنى

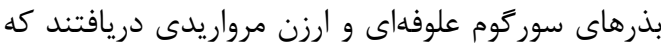
با افزايش سطوح تيمار شورى ميزان بنيه هر دو دياه

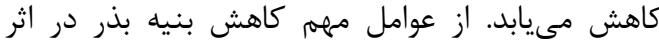

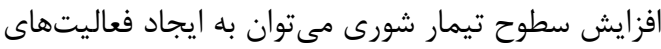

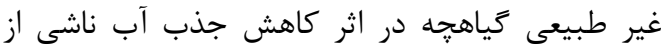
افزايش يتانسيل اسمزى حاصل از حضور يونهاى كلر و

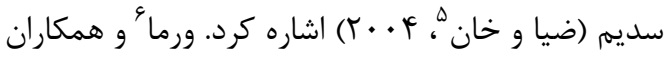

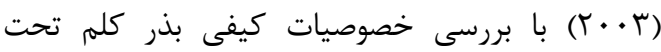
شرايط پِيرى بذر كزارش دادند كه با افزايش دوره زوال بذر از ميزان بنيه بذر كاسته شده و كاهش بنيه بذر در بر برد اثر اعمال يِيرى تسريع شده موجب كاهش استقرار كياهجه و در نهايت موجب كاهش عملكرد مى تردد. بنيه بذر تابع درصد جوانهزنى و طول كياهجه بودها ييرى بذر شاخص بنيه بذر را از طريق درصد جوانهزنى بدري

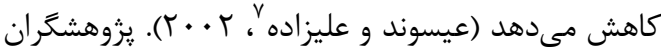
در بررسى اثر هيدرويرايمينَ روى روى بذرهاى لوتوس دريافتند كه هيدرويرايمينخ اثر لرين (Egyptian lotus)

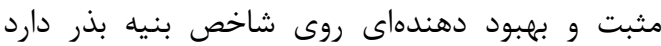

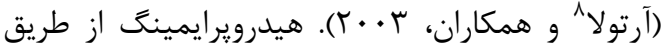
تسريع و بهبود جوانهزنى، افزايش رشد طولى و تقسيم

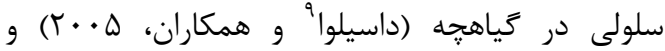

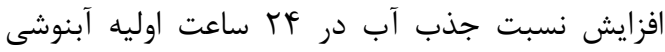

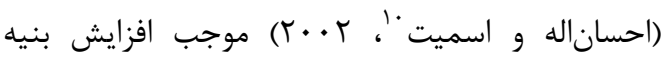
بذرها شده است.

\section{فعاليت آنزيمهاى (آلفا و بتا) آميلاز}

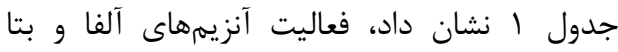
آميلاز از نظر تيمار شورى، گروه بذر و هيدرويرايمينگ

\footnotetext{
${ }^{4}$ Khalesro and Aghaalikhan

${ }^{5} \mathrm{Zia}$ and Khan

${ }^{6}$ Verma

${ }^{7}$ Eisvand and Alizadeh

${ }^{8}$ Artola

${ }^{9}$ Da Silva

${ }^{10}$ Ehsanullah and Smith
}

ضريب آلومتريك را بهدنبال دارد. خليلى اقدام و گرزين'

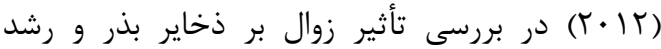

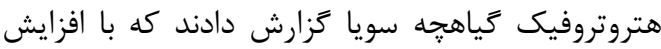

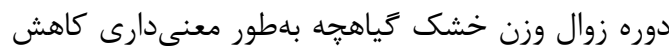
يافته كه منتج به كاهش ميزان ضريب آلومتريك در

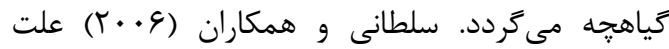
كاهش وزن خشك گياهجه و بهدنبال آن كاهش ضرئ آلومتريك را كاهش ميزان يويايى ذخاير بذر و همجنين كاهش كارآيى تبديل ذخاير يويا شده داند دانستهاند.

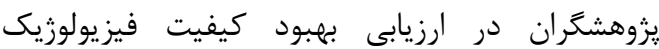
بذرهاى زوال يافته با استفاده از يرايمينگ تزارش دارئ دادند

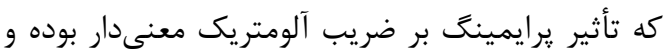
با افزايش سطوح يرايمينَ بر ميزان ضريب آلومتريك إيك

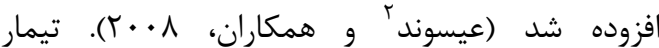
هيدرويرايمينگ بهدليل فعالسازى فعاليتهاى متابوليكى جنين مانند همانند سازى DNA، تحريك فعاليت RNA و در نتيجه افزايش يروتئينسازى، ترميم غشاى سلولى و توليد هورمونهاى تحريك كننده

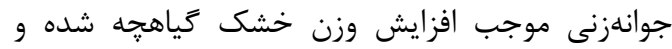
بهدنبال آن موجب افزايش ضريب آلومتريك مى

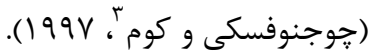

بنيه بذر تجزيه واريانس دادهها نشان داد، بنيه بذر از نظر تيمار شورى و برهمكنش تيمار شورى× هيدرويرايمينگ

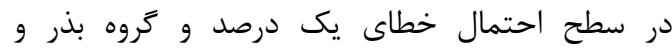
برهمكنش گروه بذرههيدرويرايمينَ در سطح احتمال

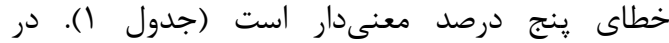
برهمكنش تيمار شورى × هيدرويرايمينگ، بيشترين

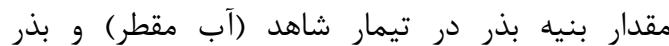

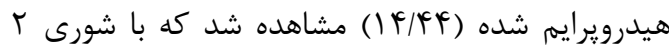
دسىزيمنس بر متر و بذر هيدرويرايم شده تفاوت معنى - دارئ

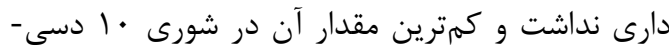

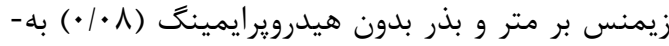

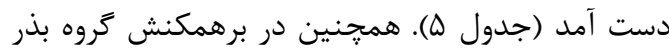

\footnotetext{
${ }^{1}$ Khalili Eghdam and Gorzin

${ }^{2}$ Eisvand

${ }^{3}$ Chojnowski and Come
} 


\section{قنبرى و همكاران: تأثير هيدرويرايمينَّ و يبيرى بذر بر ويزَى هاى جوانهزنى و بيوشيميايى بذر لوبيا...}

بذر با افزايش ميزان كلوكز بذر و افزايش تنفس كياهجه توليدى موجب تخريب آنزيمهاى آلفا و بتا آميلاز مى -

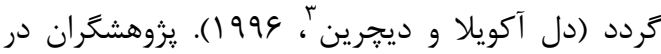

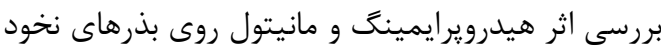
تحت شرايط تنش شورى دريافتند كه هيدرويرايمينَ اثر مثبت و بهبود دهندهاى روى فعاليت آنزيمهاى آلفاو

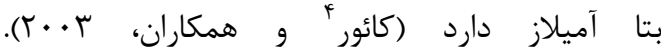
هيدرويرايمينگ از طريق تحريك سلولهاى آلئورون به ترشح بيشتر آنزيمهاى جوانهزنى از طريق افزايش تنفس إنس جنين و ترشح هورمون جيبرلين (داى هُ و همكاران، موجب افزايش فعاليت آنزيمهاى آلفاو وبتا آميلاز

\section{مالون دى آلدهيد (ريشهجه و ساقهجه)} تجزيه واريانس نشان داد كه مالون دى آلدهيد از نظر تيمار شورى، گروه بذر و هيدرويرايمينگ در سطح احتمال خطاى يك درصد معنى دار است (جدول (1). مقايسه ميانكَين دادهها نشان داد كه بيشترين ميزان مالون دى آلدهيد ريشهجه و ساقهجه در تيمار

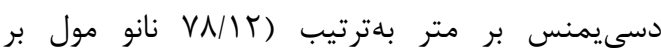
ميلى

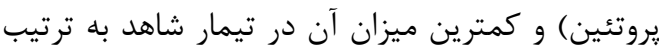

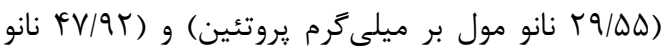
مول بر ميلى كرم يروتئين) است. همجنين از نظر كروه

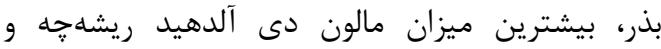

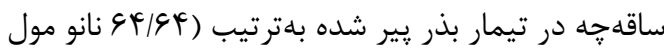
بر ميلى يروتئين) مشاهده شد. از نظر هيدرويرايمينَ نيز بيشترين ميزان مالون دى آلدهيد ريشهجه و ساقه

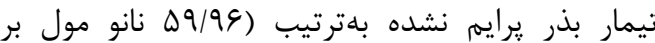
ميلى

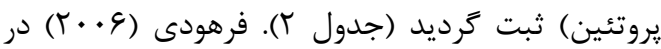

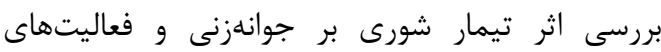
آنزيمى، نشتيذيرى غشاى سلولى و رشد گياهجه ارقام كلزا دريافت كه با افزايش سطوح تيمار شورى ميزان سئن

\footnotetext{
${ }^{3}$ Dell Aquila and Diturin

${ }^{4}$ Kaure
}

${ }^{5}$ Dai
در سطح احتمال خطاى يك درصد و فعاليت آنزيم آلفا

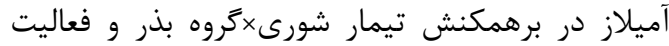

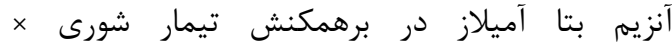
هيدرويرايمينگ در سطح احتمال خطاى ينج درصد

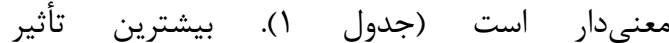

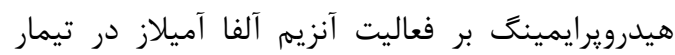

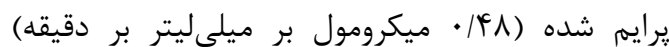

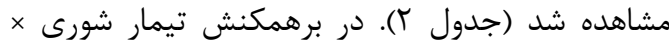
كروه بذر، بيشترين مقدار فعاليت آلفا آميلاز در تيمار

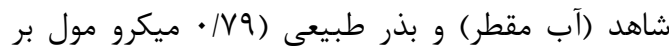

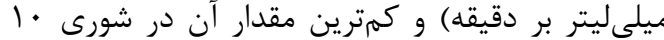

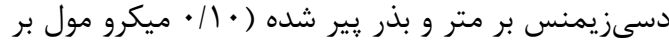

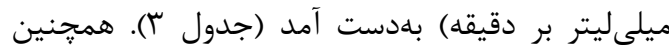
بيشترين تأثير كروه بذر بر ميزان فعاليت آنزيم بتا آميلاز

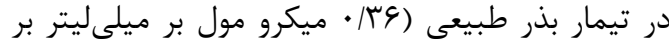
دقيقه) مشاهده شد (جدول (Y). در برهمكنش تيمار شورى × هيدرويرايمينگ، بيشترين مقدار فعاليت بتا

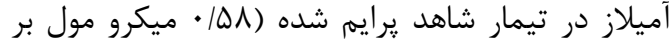

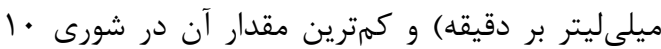

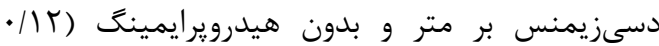
ميكرو مول بر ميلىليتر بر دقيقه) مشاهده شد (جدول

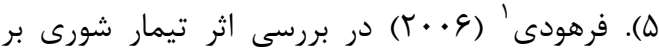

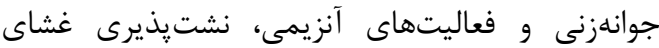
سلولى و رشد كياهجه ارقام كلزا دريافت كه با افزايش إنى سطوح تيمار شورى ميزان فعاليت آنزيمهاى آلفا و بتا آميلاز گياه كاهش مىيابد. از عوامل مهمم كاهش فعاليت آنزيمهاى جوانهزنى در اثر افزايش سطوح تيمار شورى إنى

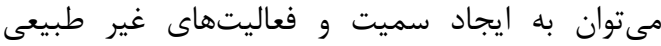
آنزيمى در اثر كاهش متابوليسم ذخاير غذايى بذر

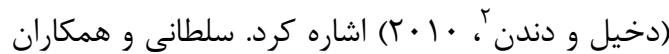

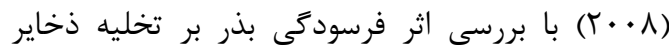
زرنتيكى بذرها و رشد هتروتروفيك گياهجه كَندم كزارش

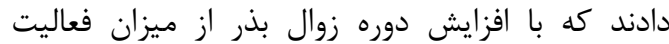
آنزيمهاى آلفا و بتا آميلاز كاسته شده و كاهش فعاليت آنزيمهاى جوانهزنى در اثر اعمال يِيرى تسريع شده موجب كاهش روند جوانهنى بذرها مى گردد. فرسودىى

\footnotetext{
${ }^{1}$ Farhoodi

${ }^{2}$ Dkhil and Denden
} 
فعاليت آنزيمهاى جوانهزنى، تأثيرات مخرب تنش شورى و زوال بذر ناشى از انباردارى را تعديل نمايد.
مالون دى آلدهيد كياه افزايش مىيابد. تيمار شورى با تجمع بيشتر يون سديم موجب تخريب شديد غشاى

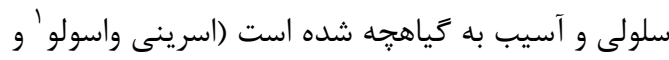

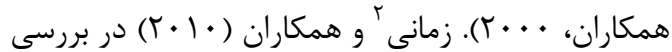

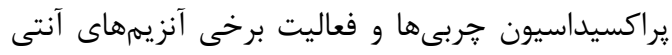

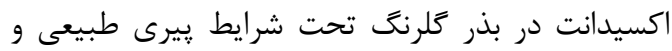

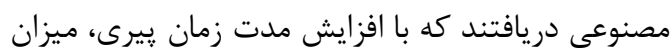

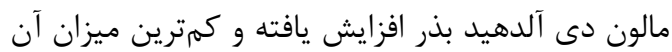

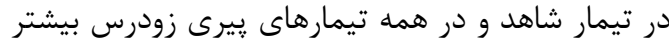

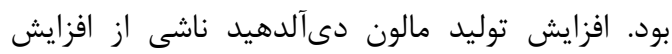
كونههاى فعال اكسيرن در بذر است كه مىتواند ناشى از

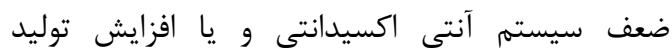

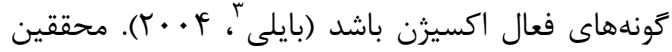
با بررسى اثر يرايمينح بذر بر آنزيمهاى آنتى اكسيدانى

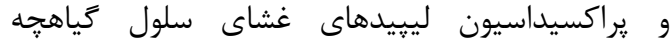

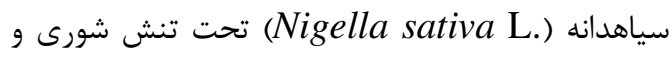
خشكى كزارش دادند كه يرايمينَ باعث كاهش ميزان مالون دى آلدهيد در بذرها شده است (احمديور

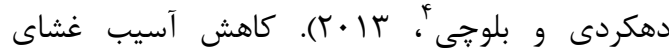

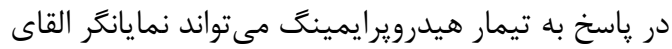

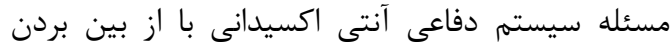

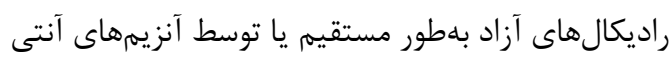
اكسيدانى باشد كه خسارت ناشى از كونههاى فعال اكسيزن را كاهش مىدهد و در نتيجه يراكسيداسيون

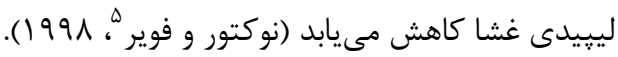
نتيجه نتايج اين يزوهش نشان داد كه با افزايش سطوح تيمار شورى و اعمال زوال بذر تمام شاخصهاى ندان

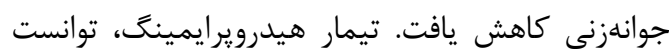
شاخصهاى جوانهزنى بذر را تحت تيمار شورى به همراه

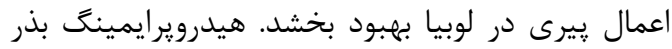
توانست از طريق افزايش ميزان بنيه بذر و افزايش ميزان

${ }^{1}$ Sreenivasulu

${ }^{2}$ Zamani

${ }^{3}$ Bailly

${ }^{4}$ Ahmadpoor Dehkordi and Balouchi

${ }^{5}$ Noctor and Foyer 
Aghabarati, A., and Maralian, H. 2011. The effect of seed deterioration on germination and vigor of maple Acer cineracens Boiss. Quarterly Journal of Natural Ecosystems Iran, 2(2): 25-35. [In Persian with English Summary].

Agrawal, R. 2003. Seed technology. Pub. Co. PVT. LTD. New Delhi, India. 829p.

Ahmadloo, F., Tabari, M., and Behtari, B. 2012. Effect of water stress and accelerated ageing on some physiological characteristics of Pinus brutia Ten. seeds. Iranian Journal of Rangelands and Forests Plant Breeding and Genetic Research, 19(2): 345-358. [In Persian with English Summary].

Ahmadpoor Dehkordi, S., and Balouchi, H.R. 2013. Effect of seed priming on antioxidant enzymes and lipids peroxidation of cell membrane in Black cumin (Nigella sativa) seedling under salinity and drought stress. Journal of Crop Production, 5(4): 63-85. [In Persian with English Summary].

Artola, A., Carrillo-Castaneda, G., and Santos, G.D.L. 2003. Hydropriming: A strategy to increase Lotus Corniculatus L. Seed vigor. Seed Science and Technology, 31: 455-463. https://doi.org/10.15258/sst.2003.31.2.22

Azarnivand, H., Zandi Esfahan, E., and Shahriary, E. 2005. Effect of salinity stress on germination of Haloxylon aphyllum, Seidlitzia rosmarinus and Hammada salicornica. Journal of Desert, 11(1): 187-196. [In Persian with English Summary].

Bailly., C. 2004. Active oxygen species and antioxidants in seed biology. Seed Science Research, 14(2): 93-107. https://doi.org/10.1079/SSR2004159

Basra, S.M.A., Ahmad, N., Khan, M.M., Iqbal, N., and Cheema, M.A. 2003. Assessment of cottonseed deterioration during accelerated aging. Seed Science and Technology, 31(3): 531540. https://doi.org/10.15258/sst.2003.31.3.02

Basra, S.M.A., Rehman, K.U., and Iqbal, S. 2000. Cottonseed deterioration: assessment of some physiological and biochemical aspects. International Journal of Agriculture and Biology, 2(3), 195-198.

Bernfeld, P. 1970. Amylase $\alpha$ and $\beta$, in methods in Enzymology. In: S. Colowick and N. Kaplan (Eds). Academic Press, New York, p. 149.

Bewley, D.J. 1997. Seed germination and dormancy. Plant Cell, 9(7): 1055-1060. https://doi.org/10.1105/tpc.9.7.1055

Chojnowski, F.C., and Come, D. 1997. Physiology and biochemical changes induced in sunflower seeds by osmopriming and drying, storage and aging. Seed Science Research, 7(4): 323-331. https://doi.org/10.1017/S096025850000372X

Cobley, L.S. 1996. An introduction to the botany of tropical crops. New York, London, Longman. $88-91$.

Da Silva, E.A.A., Toorop, P.E., Nijsse, J., Bewley, J.D., and Hilhorst, H.W.M. 2005. Exogenous gibberellins inhibit coffee (Coffea arabica L. cv. Rubi) seed germination and cause cell death in the embryo. Journal of Experimental Botany, 56(413): 1029-1038. https://doi.org/10.1093/jxb/eri096

Dai, S., Wang, T., Yan, X., and Chen, S. 2007. Proteomics of pollen development and germination. Journal of Proteome Research, 6(12): 4556-4563. https://doi.org/10.1021/pr070474y

Dell Aquila, A., and Diturin, M. 1996. The germination response to heat and salt stress in evaluation vigor loss in aged wheat seeds. Seed Science and Technology, 24: 309-319. 
Dkhil, B.B., and Denden, M. 2010. Salt stress induced changes in germination, sugars, starch and enzyme of carbohydrate metabolism in Abelmoschus esculentus L. (Moench.) seeds. African Journal of Agricultural Research, 5(12): 1412-1418.

Ehsanullah, K., and Smith, M.I. 2002. Soaking injury in relation to the rate of imbibitions in soybean (Glycine $\max$ L. Merrill). Pakistan Journal of Seed Science and Technology, 1(1): 2733.

Eisvand, H.R., and Alizadeh, M.A. 2002. The assessment of some physiological factors badrashbo (Dracocephalum moldavica) medicinal plant seed test under the terms of premature aging. Genetic Research and Correction of Forest and Pasture Plants in Iran, 11(2): 249-255. [In Persian with English Summary].

Eisvand, H.R., and Maddah Arefi, H. 2007. Effects of some plant growth regulators on the physiological quality of Bromus aged seed. Iranian Journal of Rangelands and Forest Plant Breeding and Genetic Research, 15(2): 159-171. [In Persian with English Summary].

Eisvand, H.R., Tavakkol Afshari, R., Sharifzadeh, F., Arefi, H.M., and Hesamzadeh Hejazi, S.M. 2008. Improve the physiological quality of the seeds of decline in the tall wheatgrass (Agropyron elongatum Host) using hormonal priming for stress and non-stress conditions. Iranian Journal of Field Crop Science, 39(1): 53-65. [In Persian with English Summary].

Ellis, R.H., hory, T.P., and Roberts, E.H. 1980. Towards a rational basis for testing seed quality. Proceedings-Easter School of Agricultural Science, University of Nottingham, Butterworths, London. 605-635.

Fallah, A., and Babaei, M. 2006. The assessment of salinity stress on germination of rice. Journal of Agricultural Sciences and Natural Resources, 4: 12-18. [In Persian with English Summary].

Farhoudi, R. 2006. Effect of salinity stress on alpha-amylase activity, cell membrane leakage and seedling growth of canola cultivars. Journal of Process and Plant Function, 1(1): 14-25. [In Persian with English Summary].

Farooq, M., Basra, S.M.A., Warraich, E.A., and Khaliq, A. 2006. Optimization of hydropriming techniques for rice seed invigoration. Seed Science and Technology, 34(2): 529-534.

https://doi.org/10.15258/sst.2006.34.2.25

Fowler, D.B., Gusta, L.V., and Tyler, N.J. 1981. Selection for winter hardiness in wheat. III. Screening methods. Crop Science, 21(6): 896-901. https://doi.org/10.2135/cropsci1981.0011183X002100060023x

Ghanbari, M., and Karamnia, S. 2016. Evaluation of the effect of seed aging on some characteristics of bean germination (Phaseolus vulgaris L.) landraces of Guilan province under salinity stress conditions. The 6th Iranian Pulse Crops Symposium, 4 May, Khoram-abad. [In Persian Summary].

Ghanbari, M., Mansour Ghanaei Pashaki, K., Safaei Abdolmanaf, S., and Aziz Ali-abadi, K. 2016. Effect of salt stress and hydropriming on germination characteristics of Mungbean (Vigna radiata (L.) Wilczek). Iranian Journal of Pulses Research, 7(1): 65-80. [In Persian with English Summary].

Ghasemi Golazani, K., Mohammadian, R., Moghaddam, R. and Sadegheian, Y. 1996. Effect of seed aging on germination and seedling growth had seven sugar beet breeding populations under salinity treatments. Journal of Agricultural Sciences and Natural Resources, 2(4): 39-43. [In Persian with English Summary].

Gholami Tileh-boni, H., Salehi Balashahri, M., and Farhadi, R. 2012. The effect of Priming and deterioration of seed germination and seedling growth changes of rice (Oryza sativa L.). Seed Science and Technology, 2(1): 1-13. [In Persian with English Summary]. 
Hamedi, S.E., and Bakhtiari, S. 2011. Effect of Hydro and Haloperiming on seed germination and seedling growth of red bean (Phaseolus vulgaris L.) under salt stress. The 2nd National Conference on Seed Science and Technology. Islamic Azad University, Mashhad Branch. [In Persian with English Summary].

Harris, D., Tripathi, R.S., and Joshi, A. 2000. On-farm seed priming to improve crop establishment and yield in direct-seeded rice. In, IRRI: International Workshop on Dry-seeded Rice Technology, held in Bangkok, 25-28 January 2000. International Rice Research Institute, Manila, Philippines. 164p.

Hassanzadeh Kahal Sofla, S., Taheri, G., and Mehrzad, J. 2012. Priming effects on germination of sweet corn (Zea mays cv. Basin) under sodium chloride stress. Seed Science and Technology, 2(1): 62-70. [In Persian with English Summary].

Hopkins, R.O., Waldram, K., and Kesner, R.P. 2004. Sequences assessed by declarative and procedural tests of memory in amnesic patients with hippocampal damage. Neuropsychologia, 42(14): 1877-1886. https://doi.org/10.1016/j.neuropsychologia.2004.05.008

Hosseini, F., Siadat, S.A., Bakhshandeh, A.M., and Chab, A.N. 2011. Evaluate the effect of oxygen tension on germination and seedling growth of five components of wheat. Iranian Journal of Field Crops Research, 9(4): 631-638. [In Persian with English Summary].

ISTA. 2004. International Rules for Seed Testing. International Seed Testing Association. Zurich. Switzerland.

Judi, S., and Sharizadeh, F. 2004. Investigation of hydropriming effects on barley cultivars. Journal of Desert, 11(1): 99-109.

Kaur, S., Gupta, A.K., and Kaur, N. 2002. Effect of osmo and hydro priming of chickpea seeds on seedling growth and carbohydrate metabolism under water deficit stress. Plant Growth Regulation, 37(1): 17-22. https://doi.org/10.1023/A:1020310008830

Kaur, S., Gupta, A.K., and Kaur, N. 2003. Priming of chickpea seeds with water and Mannitol overcomes the effect of salt stress on seedling growth. International Chickpea and Pigeon pea Newsletter, 10: 18-20.

Khajeh-Hosseini, M., Powell, A.A., and Bingham, I.J. 2003. The interaction between salinity stress and seed vigor during germination of soybean seeds. Seed Science and Technology, 31(3): 715-725. https://doi.org/10.15258/sst.2003.31.3.20

Khalesro, Sh., and Aghaalikhani, M. 2007. Effect of salinity and water Deficit stress on seed germination. Pajouhesh \& Sazandegi. 77: 153-163. [In Persian with English Summary].

Khalili Eghdam, N., and Gorzin, O. 2012. Effect of deterioration on the discharge of seeds and growth of heterotrophic soybean seedlings. Journal of Seed Science and Technology, 1(1): 2933. [In Persian with English Summary].

Kochaki, A., and Zarif Ketabi, H. 1996. Determine the optimum temperature for germination and monitored for salinity and drought effects of several range species. Journal of Desert, 1(1): 2436. [In Persian with English Summary].

Mahdavi, M. 2005. Applied hydrology. Tehran University Press. 362p. [In Persian].

Mashi, A., and Galeshi, S. 2007. The effect of salinity on germination indexes of four Hull-less barley genotypes. Journal of Agricultural Sciences and Natural Resources, 13(6): 45-57. [In Persian with English Summary].

McDonald, M.B. 2000. Seed priming. In Black, M., and Bewley, J.D. (ed.). Seed technology and Its Biological Basis. Sheffield Acad. Press, Sheffield, England. 287-326.

Noctor, B., and Foyer, C.H. 1998. Ascorbate and glutathione: Keeping active oxygen under control. Annual Review Plant Physiology, 49(1): 249-279. 
https://doi.org/10.1146/annurev.arplant.49.1.249

Parsa, M., and Bagheri, A.R. 2013. Legumes. Mashhad Jihad University Press, 528P. [In Persian].

Rajabi, R., and Postini, K. 2005. Effects of $\mathrm{NaCl}$ on thirty cultivars of bread wheat seed germination. Agriculture Science Journal, 27: 29-45.

Redmann, R.E., Q1, M.Q., and Belyk, M. 1994. Growth of transgenic and standard canola (Brassica napus L.) varieties in response to soil salinity. Plant Science, 74(4): 797-799. https://doi.org/10.4141/cjps94-142

Salim, M. 1991. Comparative growth responses and ionic relations of four cereals during salt stress. Journal of Agronomy and Crop Science, 166(3): 204-209.

https://doi.org/10.1111/j.1439-037X.1991.tb00905.x

Samiei, D. 2000. Green beans. Promotion magazine, Production office and promotion and technical Publishing Department of the Ministry of Jihad-e-Keshavarzi. [In Persian].

Shoeoan, I.S., and Garo, O.P. 1985. Effect of different types of salinities during germination: Seedling growth and water relation. Indian Journal of Plant Physiology, 26: 263-369.

Sivritepe, N., Sivritepe, H.O., and Eris, A. 2003.The effects of $\mathrm{NaCl}$ priming on salt tolerance in melon seedling grown under saline conditions. Scientia Holticuturae, 97(3-4): 229-237. https://doi.org/10.1016/S0304-4238(02)00198-X

Soltani, A., Galeshi, S., Zeinali, E., and Latifi, N. 2001. Genetic variation for and interrelationships among seed vigor traits in wheat from the Caspian Sea coasts of Iran. Seed Science and Technology, 29: 653-662.

Soltani, A., Gholipoor, M., and Zeinali, E. 2006. Seed reserve utilization and seedling growth of wheat as affected by drought and salinity. Environmental and Experimental Botany, 55(1-2): 195-200. https://doi.org/10.1016/j.envexpbot.2004.10.012

Soltani, E., Kamkar, B., Galeshi, S., and Akram Ghaderi, F. 2008. The effect of seed deterioration on seed reserves depletion and heterotrophic seedling growth of wheat. Journal of Agricultural Sciences and Natural Resources, 15(1): 182-193. [In Persian with English Summary].

Sreenivasulu, N., Grimm, B., Wobns, U., and Weschke, W. 2000. Differential response of antioxidant compounds to salinity stress in salt-tolerant and salt-sensitive seedling of foxtail millet. Physiology Plantarum, 109: 435-442. https://doi.org/10.1034/j.1399-3054.2000.100410.x

Srinivasan, K., and Saxena, S. 2001. Priming seeds for improved viability and storability in Raphanus sativus cv. Chinese Pink. Indian Journal of Plant Physiology, 6: 271-274.

Tamartash, R., Shokrian, F., and Kargar, M. 2010. Effects of salinity and drought stress on Trifolium alexanderium L. seed germination properties. Rangeland, 4(2): 288-297. [In Persian with English Summary].

Tavili, A., Saberi, M., Jafari, M., Safari, B., and Sadeghi Sangdehi, A. 2009. Influence of salinity and temperature on germination of Trifolium alexanderinum. Journal of Plant Ecophysiology, 1(1): 18-28. [In Persian with English Summary].

Verma, S.S., Verma, U., and Tomer, R.P.S. 2003. Studies on seed quality parameters in deterioration seeds in Brassica (Brassica campestris). Seed Science and Technology, 31(2): 389-398. https://doi.org/10.15258/sst.2003.31.2.15

Windauer, L., Altuna, A., and Benech-Arnold, R. 2007. Hydrotime analysis of Lesquerella fendleri seed germination responses to priming treatments. Industrial Crops and Products, 25(1): 70-74. https://doi.org/10.1016/j.indcrop.2006.07.004

Zamani, A., Sadat Nouri, S.A., Tavakol Afshari, R., Iran Nejad, H., Akbari, Gh.A., and Tavakoli, A. 2010. Evaluation of lipid peroxidation and activity of antioxidant enzymes in safflower seed 
under natural and artificial aging. Iranian Journal of Crop Science, 41(3): 545-554. [In Persian with English Summary].

Zia, S., and Khan, M.A. 2004. Effect of light salinity and temperature on seed germination of Limonium stocksii. Canadian Journal of Botany, 82(2): 151-157. https://doi.org/10.1139/b03$\underline{118}$ 


\title{
Effect of Hydropriming and Seed Aging on Seed Germination and Biochemical Characteristics of Pinto Bean (Phaseolus vulgaris) Seed under Salt Stress
}

\author{
Majid Ghanbari ${ }^{1,}$, , Seyed Ali Mohammad Modarres-Sanavy², Ali Mokhtassi Bidgoli ${ }^{3}$, \\ Parniyan Talebi-Siah Saran ${ }^{4}$ \\ ${ }^{1}$ Ph.D. Candidate of Crop Physiology, Tarbiat Modares University, Tehran, Iran \\ ${ }^{2}$ Professor of Crop Physiology, Tarbiat Modares University, Tehran, Iran \\ ${ }^{3}$ Assistant Professor of Agronomy, Tarbiat Modares University, Tehran, Iran \\ ${ }^{4}$ M.Sc., Tarbiat Modares University, Tehran, Iran \\ * Corresponding author, E-mail address: majid.ghanbari@modares.ac.ir
}

(Received: 03.03.2017 ; Accepted: 30.01.2018)

\begin{abstract}
This study was conducted to evaluate the effect of hydropriming and seed aging on germination and enzymatic properties of pinto bean under salinity stress as factorial based on a completely randomized design with four replications. Two groups of seeds (i.e., non-aged and aged seeds), two hydropriming treatments (i.e., hydro primed and unprimed seeds) and six salinity treatments (i.e., 0 , $2,4,6,8$ and $10 \mathrm{dS} / \mathrm{m}$ ) were the experimental factors. The results showed that the highest mean time and percentage of germination, plumule length and vigor were observed in the control (i.e., distilled water) and hydropriming treatments. Maximum root length and percentage of seedling water were obtained in the control (i.e., distilled water) and aged seed treatments. In addition, in terms of radicle dry weight, the highest amount was observed in salinity of $4 \mathrm{dS} / \mathrm{m}$ and non-aged hydro primed seeds. The highest plumule dry weight was observed in salinity of $6 \mathrm{dS} / \mathrm{m}$ and allometric index in salinity of $8 \mathrm{dS} / \mathrm{m}$ for non-aged seed and aged seed without hydropriming, respectively. An increase in the levels of salinity stress and aging the seeds increased the malondialdehyde and reduced the activity of germination, mean time and germination percentage, and seedling growth. Seed hydropriming reduced the peroxidation of the cell membrane and generally improved the speed and uniformity of germination, aged and natural seeds vigor under both salinity and optimum conditions. As a result, hydropriming can increase the tolerance of bean seeds to salinity at the germination stage and increase the germination capacity of stored seeds for cultivation.
\end{abstract}

\section{Keywords: Salt, Pre-sowing hydration, Seed aging, Germination, Bean}

\section{Highlights:}

1- The effect of hydropriming on recovering the power of seed germination of pinto bean has been studied under the salinity condition.

2- An attempt has been made to determine the effect of hydropriming on increasing the tolerance of pinto bean seeds to storage and salinity stress condition.

3- The effect of pinto bean storage on biochemical changes and enzyme activity has been studied in salinity stress condition.

DOI: 10.29252/yujs.4.2.37 